Review Article

\title{
Orchestration of Adaptive T Cell Responses by Neutrophil Granule Contents
}

\author{
Danielle Minns (D, Katie Jane Smith (D), and Emily Gwyer Findlay (D) \\ Centre for Inflammation Research, School of Medicine and Veterinary Medicine, University of Edinburgh, Edinburgh EH16 4TJ, UK \\ Correspondence should be addressed to Emily Gwyer Findlay; emily.findlay@ed.ac.uk
}

Received 30 November 2018; Revised 28 January 2019; Accepted 6 February 2019; Published 10 March 2019

Academic Editor: Mirella Giovarelli

Copyright ( 2019 Danielle Minns et al. This is an open access article distributed under the Creative Commons Attribution License, which permits unrestricted use, distribution, and reproduction in any medium, provided the original work is properly cited.

\begin{abstract}
Neutrophils are the most abundant leukocytes in peripheral blood and respond rapidly to danger, infiltrating tissues within minutes of infectious or sterile injury. Neutrophils were long thought of as simple killers, but now we recognise them as responsive cells able to adapt to inflammation and orchestrate subsequent events with some sophistication. Here, we discuss how these rapid responders release mediators which influence later adaptive $\mathrm{T}$ cell immunity through influences on DC priming and directly on the $\mathrm{T}$ cells themselves. We consider how the release of granule contents by neutrophils-through NETosis or degranulation-is one way in which the innate immune system directs the phenotype of the adaptive immune response.
\end{abstract}

\section{Neutrophils Are Sophisticated Cells Able to Adapt to Changing Inflammation}

Neutrophils are not simple bags of enzymes sent to kill pathogens before the adaptive immune cells move in. In fact, they are able to respond to altered inflammatory status; neutrophils can produce cytokines [1], alter their gene expression during inflammation [2] and throughout "aging" [3], and survive for significantly longer than traditionally thought, with one study placing lifespan from bone marrow at 5.4 days [4]. As a consequence, neutrophils are able to adapt to changing conditions and direct other cells' behaviour-a task which they can perform with some sophistication.

\section{The Adaptive T Cell Response Generates in the Presence of Neutrophil Mediators}

As adaptive immune responses develop, $\mathrm{T}$ cells are primed by dendritic cells (DCs) in the lymph node and proliferate in situ before moving into the tissue where their antigen of interest is situated. Here, they encounter antigen, receive additional signals from antigen-presenting cells (APCs) and local cytokines, and carry out their effector functions. However, this response does not happen in isolation. The DCs scanning for antigen in the respiratory tract during influenza infection, for example, also encounter millions of neutrophils, which can out number them manyfold $[5,6]$, as do the influenza-specific $T$ cells which subsequentlyleave thelymph node at the peak of inflammation. As these neutrophils will be degranulating, dying, and producing extracellular traps (NETs, [7]), the DC and T cells are in effect moving into a soup of neutrophil-produced inflammatory mediators. It is no surprise that these mediators have profound effects on $\mathrm{T}$ cell differentiation, survival, proliferation, and effector function.

In this review, we will consider how the granule contents released during neutrophil degranulation and NETosis affect the development of adaptive $\mathrm{T}$ cell responses. We are discussing extruded mediators only, and not the antigen-presentation capacities or cell-cell interactions performed by neutrophils nor the outcomes of whole apoptotic or necrotic neutrophils being engulfed. It is our contention that the inflammatory mediators released by neutrophils allow these innate cells to exert some control over the tissue environment and direct later adaptive immune responses.

\section{Conflicting Data on How Neutrophils Affect T Cell Responses}

Recent years have seen an explosion of research into how neutrophils affect DC and T cell biology; however, these data 
are confusing, with neutrophils either suppressing or promoting $\mathrm{T}$ cell activation depending on the context (Figure 1).

There are a number of murine models in which the $\mathrm{T}$ cell responses can be exacerbated by depleting neutrophils, implying they have a regulatory role $[8,9]$. This suppression of $\mathrm{T}$ cell responses by neutrophils requires close contact and development of an immunological synapse [10,11]—perhaps as the mediators thought responsible, reactive oxygen species and $\mathrm{H}_{2} \mathrm{O}_{2}$ do not diffuse far. Uptake of apoptotic or necrotic neutrophils also inhibits DC antigen presentation and costimulation, resulting in reduced $\mathrm{T}$ cell responses - a situation which can be exploited by pathogens. For example, neutrophils capture L. major and are subsequently engulfed by DCs, suppressing antigen presentation and T cell priming [12, 13].

In the second group of research, neutrophils are proinflammatory and promote $T$ cell responses. Neutrophils induce the migration, maturation, proinflammatory cytokine production, and priming capabilities of DCs through contactand cytokine/chemokine-dependent mechanisms [14-23]. Depletion of neutrophils in mouse models of inflammatory disease leads to decreases in virus-specific $\mathrm{CD}^{+} \mathrm{T}$ cell responses [24] and a lack of skewing to protective subsets $[25,26]$. Further, neutrophils can directly present antigen to $\mathrm{T}$ cells and directly stimulate $\mathrm{T}$ cell proliferation in response to superantigen [27-31].

It is not yet clear why and how these two situations exist. It may reflect the presence of different populations of neutrophils [32] which are not yet stratified; for example, the maturation status of neutrophils released from the bone marrow during sepsis, which are suppressive to T cells [10], differs markedly from those present in the highly inflammatory environment of hyperlipidemia [33], which are primed and produce high levels of myeloperoxidase. In addition, the ability of neutrophils to alter their expression of surface molecules and to transcribe RNA once they have left the bone marrow means the generation of localised populations of cells may well have differential effects on adaptive immunity (reviewed in [34]).

Other possibilities are that the different effects noted are a consequence of the inflammatory model or infection used or of particular features of dendritic cell or $\mathrm{T}$ cell biology that are only expressed in certain inflammatory states; the situation may also reflect different experimental techniques, particularly for the isolation of neutrophils (see Section 5 - a note on immature and low density neutrophils). Further, murine and human neutrophils do differ in many ways (reviewed in [35]) and use of mouse models must be considered as a variable.

In this review, we attempt to discuss a number of ways in which neutrophil granule contents affect priming, differentiation, and survival of $\alpha \beta$ T cells. These granule peptides also show a variety of effects, with both suppressive and activatory impacts on T cell immunity-we discuss the complexity of these responses.

\section{Impact of Neutrophil Granule Contents of DC-T Cell Immunity}

4.1. Degranulation. Degranulation is the exocytosis of antimicrobial or cytotoxic molecules from intracellular granules, which functions as a defence mechanism to kill invading microbes. Neutrophils are activated and undergo degranulation through a variety of ligands (including LPS, IL-8, fMLF, and $\mathrm{C} 5 \mathrm{a}$ ) binding to cell-surface receptors which include $\mathrm{G}$ protein-coupled receptors (GPCR), Fc-receptors (Fc-R), pattern recognition receptors (PRRs), and chemokine receptors [36-38].

Following neutrophil activation, different granules possess distinct propensities for extracellular release. Neutrophil granules are divided into different subsets-primary (azurophilic), secondary (secretory), and tertiary (gelatinase) granules in addition to secretory vesicles (SVs). The different granules are formed sequentially during neutrophil differentiation and are released in the opposite order; the timing of synthesis determines the sequence in which the granules are released [39-42]. The strict hierarchy of release is secretory vesicles then tertiary, secondary, and finally primary granules [37].

Proteomic analysis delineating granule contents $[43,44]$ reveals that primary granules contain myeloperoxidase (MPO), serine proteases cathepsin G and neutrophil elastase (NE), and alpha defensins; secondary granules contain antimicrobial proteins and peptides including lactoferrin and cathelicidin (hCAP-18), pentraxin and haptoglobin, and some metalloproteinases (MMPs); finally, tertiary granules contain gelatinase, lysozyme, and some MMPs.

In this section, we discuss the contribution of components of these granules to T cell immunity. Table 1 lists a summary of results for prominent mediators from each granule.

4.1.1. Myeloperoxidase. MPO is a $150 \mathrm{kDa}$ cationic dimeric protein which produces hypochlorous acid from $\mathrm{H}_{2} \mathrm{O}_{2}$ and chloride during the respiratory burst; it is present in the primary granules and is an important antimicrobial agent $[45,46]$.

MPO-specific $\mathrm{CD}^{+} \mathrm{T}$ cells are present in patients with anti-MPO glomerulonephritis (GN) [47-49]; these can mediate glomerular injury directly as they recognise MPO released from neutrophils undergoing degranulation, apoptosis, and NETosis, inducing [50] delayed-type hypersensitivity through enhanced IFN- $\gamma$ production. Immunising mice with MPO in this model leads to increased infiltration of $\mathrm{CD}^{+} \mathrm{T}$ cells [48]. Likewise, direct injection of MPO during a model of anti-MPO glomerulonephritis induced significant IL-17A production and development of an MPO-specific DTH response as well as renal disease [51]. Therefore, in this particular inflammatory disease, MPO induces strongly proinflammatory $\mathrm{T}$ cell responses owing to it being an autoantigen.

However, in other forms of glomerulonephritis where MPO is not an autoantigen (including antiglomerular basement membrane GN and pristine-induced lupus nephritis), endogenous MPO suppresses $\mathrm{T}$ cell responses. Here, $\mathrm{MPO}^{-1-}$ mice showed increased $\mathrm{CD}^{+} \mathrm{T}$ cell accumulation and proliferation suggesting MPO attenuates $\mathrm{T}$ cell responses $[52,53]$. MPO has profoundly suppressive effects on DC and $\mathrm{CD}^{+} \mathrm{T}$ cells in vitro and in vivo. $\mathrm{MPO}$ inhibits ConA-induced proliferation of human $\mathrm{T}$ cells in vitro [54], and $\mathrm{CD}^{+} \mathrm{T}$ cells have increased activation, proliferation, and proinflammatory cytokine production in $\mathrm{MPO}^{-/-}$mice 


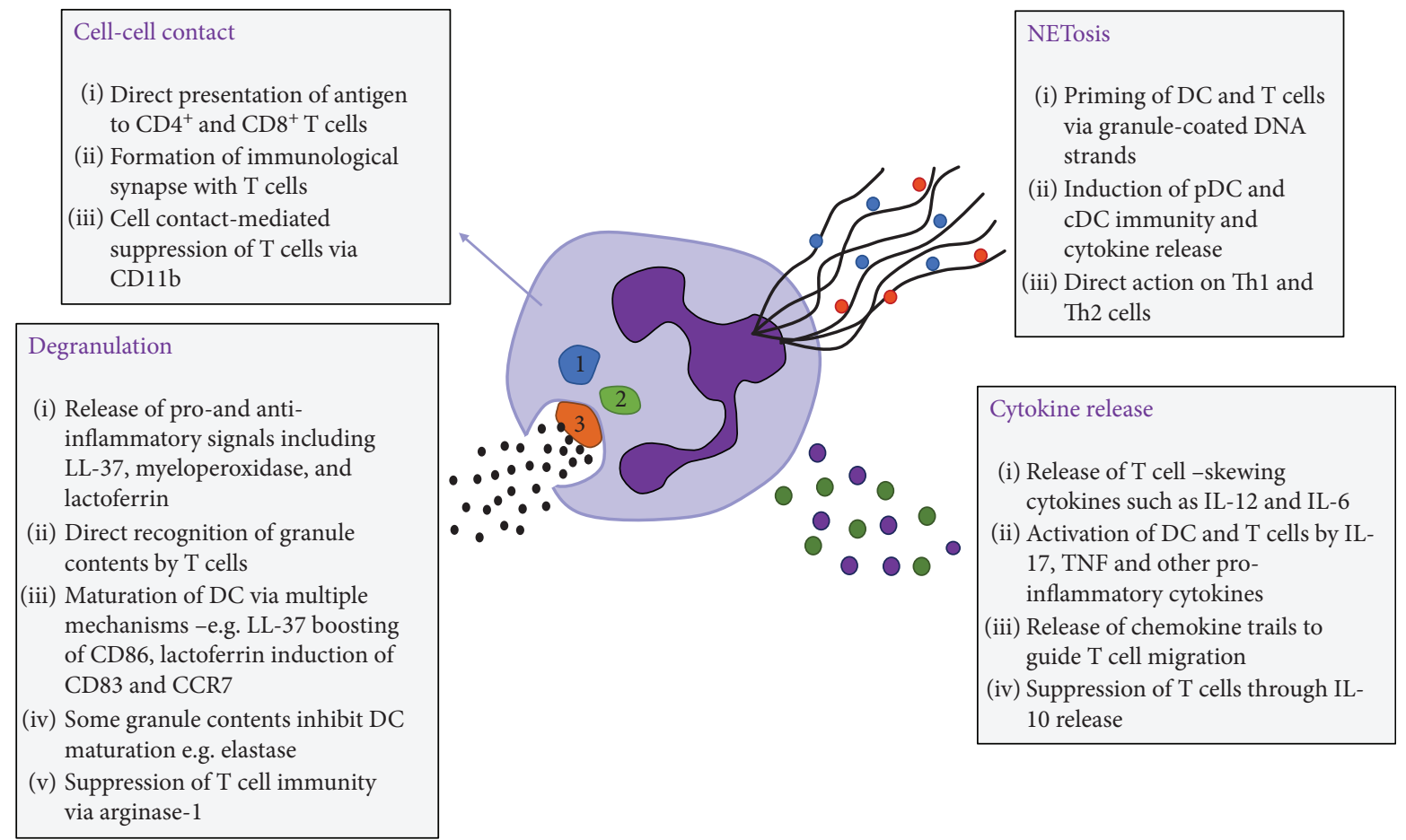

FIGURE 1: Neutrophils impact T cell immunity through many methods. Neutrophils undergo cell-cell contact, NETosis, degranulation, and cytokine release which affects T cell responses by either activating or suppressing their function. (1) Primary granules, (2) secondary granules, and (3) tertiary granules.

[55]. This was mediated by neutrophils depositing MPO in lymph nodes, where it decreases DC migration and activation. In agreement with this, mice lacking MPO have enhanced $\mathrm{T}$ cell immunity and more severe antigen-induced arthritis [55].

In addition, the reactive intermediate taurine chloramine, formed as a result of MPO-catalyzed reactions, inhibits the release of TNF- $\alpha$, IL- 6 , and IL-12 from murine DC and inhibits the capacity of DC to induce the release of IL-2 and IL-10 from $\mathrm{T}$ cells in vitro therefore suppressing $\mathrm{T}$ cell activity $[56,57]$.

It is important to note that the majority of work demonstrating a proinflammatory T cell response to MPO has been performed in patients with anti-MPO glomerulonephritis and vasculitis, who present with ANCA (antineutrophil cytoplasmic antibodies) which react to proteinase 3 and MPO in particular; this disease may involve unusual mechanisms of action of MPO not found in healthy individuals including it acting as an autoantigen.

4.1.2. Alpha Defensins. The human neutrophil peptides (HNP1-3), also known as $\alpha$-defensins, are small (c. $4 \mathrm{kDa}$ ), cationic, amphipathic antimicrobial peptides which are highly abundant in neutrophils, comprising 30-50\% of the protein content of primary granules; they are not present in mouse neutrophils (entertainingly reviewed in [58]).

Firstly, $\alpha$-defensins can induce migration of adaptive immune cells. HNP1 chemoattracts T cells [59-61] and immature DC, although data is conflicting on this point, with one report showing an increase in migration of naïve $\mathrm{CD} 4^{+} \mathrm{T}$ cells only [61] and another showing memory cell migration was also increased [60]. Stimulation of lung epithelial cells with HNP leads to increased adhesion of $\mathrm{CD}^{+} \mathrm{T}$ cells [62] and production of IFN- $\gamma$, IL-2, and IL-8. Adhesion is promoted by increased expression of CD28 and LFA1 on the $\mathrm{T}$ cells enabling increased binding to epithelial CD80, CD86, and ICAM1.

Once they are in close proximity, HNP1 can induce pDC to produce IFN- $\alpha$ [63] via degradation of I- $\kappa \mathrm{B} \alpha$ and nuclear translocation of IRF1. Similar signalling is seen in $\mathrm{CD}^{+} \mathrm{T}$ cells; HNP induces translocation of NF- $\kappa \mathrm{B}$ p50 to the nucleus and induced degradation of I-kB [62]. HNP1 also promotes an increase in the costimulatory molecules CD80, CD86, and CD40 on human monocyte-derived DC [64] as well as maturation markers. In a mixed lymphocyte reaction, DC treated with HNP1 increased T cell proliferation.

Interestingly, there are concentration-dependent outcomes following the exposure of human monocyte-derived DC to $\alpha$-defensins [65]. Low-medium doses of HNP1-3 (up to $1 \mu \mathrm{g} / \mathrm{ml}$ ) led to a slight increase in CD86 and HLA-DR expression, while higher doses inhibited the expression of these molecules. Likewise, low dose increased DC production of IL-1 $\beta$, TNF, IL-12p40, and IL-10, while higher doses inhibited this strongly. Consequently, low dose of HNP1-3 increased the DC stimulation of T cell proliferation, and high dose reduced this.

4.1.3. Neutrophil Elastase. Neutrophil elastase (ELANE, NE) is a potent serine protease with broad specificity stored in the primary azurophil granules alongside MPO and 
TABLE 1: Abundant contents of neutrophil granules and their impact on T cell immunity.

\begin{tabular}{|c|c|c|c|c|c|}
\hline Mediator & Granule & Effect on DC/T cells & Outcome & Species & Reference \\
\hline \multirow{7}{*}{ MPO } & \multirow{7}{*}{ Primary } & Is a $\mathrm{T}$ cell antigen & Activatory & $\begin{array}{l}\text { Human, } \\
\text { mouse }\end{array}$ & {$[47,48]$} \\
\hline & & Induces IL-17A production, due to being an autoantigen & Activatory & Mouse & {$[51]$} \\
\hline & & Suppresses lymphocyte proliferation & Suppressive & Human & {$[54]$} \\
\hline & & Suppresses $\mathrm{CD} 4^{+} \mathrm{T}$ cell responses & Suppressive & Mouse & [55] \\
\hline & & Suppresses DC activation and cytokine production & Suppressive & $\begin{array}{l}\text { Mouse, } \\
\text { human }\end{array}$ & {$[53,55]$} \\
\hline & & $\mathrm{MPO}^{-/-}$mice have enhanced $\mathrm{T}$ cell responses in arthritis & Suppressive & Mouse & [55] \\
\hline & & $\mathrm{MPO}^{-/-}$mice have increased $\mathrm{T}$ cell responses in nephritis & Suppressive & Mouse & {$[52,53]$} \\
\hline \multirow{9}{*}{ HNPs } & \multirow{9}{*}{$\begin{array}{l}\text { Primary (only } \\
\text { human) }\end{array}$} & $\begin{array}{l}\text { Low dose: matures, activates, and induces cytokine secretion } \\
\text { by DC }\end{array}$ & Activatory & Human & {$[65]$} \\
\hline & & Chemoattracts naïve but not memory $\mathrm{T}$ cells & Activatory & Human & {$[61]$} \\
\hline & & Chemoattracts naïve and memory $\mathrm{T}$ cells & Activatory & Human & {$[60]$} \\
\hline & & Are produced by monocyte-derived DC & Activatory & Human & [118] \\
\hline & & HNP1 induces pDC to produce IFN $\alpha$ & Activatory & Human & {$[63]$} \\
\hline & & Enhances T cell adhesion to lung epithelium & Activatory & Human & {$[62]$} \\
\hline & & Induces NF- $\kappa \mathrm{B}$ signalling in $\mathrm{CD} 4^{+} \mathrm{T}$ cells & Activatory & Human & {$[62]$} \\
\hline & & HNPs are anti-inflammatory to DC & Suppressive & Human & [169] \\
\hline & & High dose: inhibits activation, induces IL-8 & Suppressive & Human & {$[65]$} \\
\hline \multirow{7}{*}{ Elastase } & \multirow{7}{*}{ Primary } & Is a $T$ cell antigen & Activatory & Human & {$[71]$} \\
\hline & & Strongly promotes Th17 responses via cleavage of DC CXCL8 & Activatory & Human & {$[72]$} \\
\hline & & Induces DC to prime Treg & Suppressive & Human & [69] \\
\hline & & Induces $\mathrm{DC}$ to produce TGF- $\beta$ & Suppressive & Human & {$[68]$} \\
\hline & & Suppresses $\mathrm{T}$ cell proliferation in an MLR & Suppressive & Human & {$[68]$} \\
\hline & & Reduces $\mathrm{T}$ cell transmigration & Suppressive & Human & {$[66]$} \\
\hline & & Inhibits DC maturation and suppresses costimulation & Suppressive & Human & {$[70]$} \\
\hline \multirow{16}{*}{ LL-37 } & \multirow{16}{*}{ Secondary } & Is a $\mathrm{T}$ cell antigen & Activatory & Human & [73] \\
\hline & & Induces proliferation $\mathrm{CD}^{+}{ }^{+} \mathrm{T}$ cells $(+\mathrm{PHA})$ & Activatory & Human & {$[74]$} \\
\hline & & Is a chemoattractant for $\mathrm{CD}^{+} \mathrm{T}$ cells (FPR2 dependent) & Activatory & $\begin{array}{l}\text { Human, } \\
\text { mouse }\end{array}$ & $\begin{array}{l}{[61,77,} \\
78]\end{array}$ \\
\hline & & Activates $\mathrm{CD}^{+} \mathrm{T}$ cells and induces degranulation & Activatory & Mouse & [75] \\
\hline & & Matures DC primes Th1 responses & Activatory & Human & {$[80]$} \\
\hline & & Complexes DNA and is taken up by pDC & Activatory & Human & {$[82,84]$} \\
\hline & & Enhances vaccination against tumour model & Activatory & House & {$[85]$} \\
\hline & & Induces DC CD86 and migration to CCR7 ligands & Activatory & Mouse & {$[81]$} \\
\hline & & $\begin{array}{c}\text { Boosts T cell proliferation and cytokine production at } \\
\text { immunisations }\end{array}$ & Activatory & Mouse & {$[78]$} \\
\hline & & $\begin{array}{l}\text { Is internalised into cytoplasm and nucleus of DC, inducing } \\
\qquad \text { CD86 }\end{array}$ & Activatory & Human & {$[170]$} \\
\hline & & Induces apoptosis Treg & Activatory & Mouse & {$[90]$} \\
\hline & & Induces apoptosis $\mathrm{CD} 8^{+} \mathrm{T}$ cells & Suppressive & Mouse & [89] \\
\hline & & Prevents development Th2 in vitro & Suppressive & Mouse & [91] \\
\hline & & Suppresses IFN- $\gamma$ activation of DC & Suppressive & Human & {$[86]$} \\
\hline & & Inhibits DC responses to TLR4 ligands & Suppressive & Mouse & {$[87]$} \\
\hline & & Inhibits TLR signalling to DC & Suppressive & Human & {$[88]$} \\
\hline \multirow{3}{*}{ Lactoferrin } & \multirow{3}{*}{ Secondary } & Is taken up by $\mathrm{T}$ cells & & Pig & {$[107]$} \\
\hline & & Matures and activates DC & Activatory & Human & $\begin{array}{l}{[92,94,} \\
96]\end{array}$ \\
\hline & & Promotes $\mathrm{T}$ cell proliferation and Th1 generation & Activatory & Human & \\
\hline
\end{tabular}


TABLe 1: Continued.

\begin{tabular}{|c|c|c|c|c|c|}
\hline Mediator & Granule & Effect on DC/T cells & Outcome & Species & Reference \\
\hline & & & & & $\begin{array}{l}{[92,94} \\
96]\end{array}$ \\
\hline & & Increases inflammation during DTH response & Activatory & Mouse & {$[95]$} \\
\hline & & $\begin{array}{c}\text { Boosts CD } 4^{+} \text {IFN- } \gamma \text { production in concert with BCG } \\
\text { vaccination }\end{array}$ & Activatory & Mouse & [97] \\
\hline & & Upregulates the CD4 molecule & Activatory & Human & {$[100]$} \\
\hline & & Increases $\mathrm{T}$ cell cytokine production during infection & Activatory & Mouse & {$[101]$} \\
\hline & & Increases intestinal $\mathrm{CD} 8^{+} \mathrm{T}$ cell activation & Activatory & Mouse & {$[108]$} \\
\hline & & $\begin{array}{c}\text { Decreases proinflammatory } \mathrm{CD} 4^{+} \text {cells in intestinal } \\
\text { inflammation }\end{array}$ & Suppressive & Mouse & [111] \\
\hline & & Prevents $\mathrm{T}$ cell proliferation in an MLR & Suppressive & Human & [113] \\
\hline & & Prevents Th1 but not Th2 proliferation & Suppressive & Human & [114] \\
\hline \multirow{3}{*}{ Arginase-1 } & \multirow{3}{*}{ Tertiary } & Suppresses T cell proliferation via TCR-zeta & Suppressive & $\begin{array}{l}\text { Human, } \\
\text { mouse }\end{array}$ & {$[115,117]$} \\
\hline & & Induces cell cycle arrest & Suppressive & Human & {$[118]$} \\
\hline & & Inhibits development of immunological synapse & Suppressive & Human & {$[120]$} \\
\hline Gelatinase & Tertiary & Induces DC migration and T cell priming in DTH & Activatory & Mouse & {$[125]$} \\
\hline
\end{tabular}

MPO: myeloperoxidase; DC: dendritic cell; HNP: human neutrophil peptide; pDC: plasmacytoid dendritic cell; IFN- $\alpha$ : interferon- $\alpha$; NF- $\kappa \beta$ : nuclear factor-kappa beta; MLR: mixed lymphocyte reaction; PHA: phytohemagglutinin; FPR2: formylpeptide receptor 2; IFN $\gamma$ : interferon-gamma; TLR: toll-like receptor; DTH: delayed-type hypersensitivity.

$\alpha$-defensins. However, unlike the others, elastase shows mostly anti-inflammatory and regulatory roles (aside from its bacterial-killing capabilities).

Neutrophils transmigrating to sites of inflammation secrete elastase [66] which suppresses later SDF-1-induced $\mathrm{T}$ cell transmigration (but not subsequent neutrophil migration). This suppression was found to be elastase dependent.

In macrophages, elastase cleaves TLR2, TLR4, and MD-2 [67], suppressing proinflammatory cytokine production and impairing host defence in a pneumonia model. We do not yet know whether a similar phenomenon occurs with DC, but elastase does induce human immature DC-but not fully mature cells-to shut off IL-6 production and increase TGF- $\beta[68,69]$. In a mixed lymphocyte reaction, DC treated with elastase showed a twofold increase in regulatory $\mathrm{T}$ cell generation compared to control-treated cells [69] and an overall suppression of lymphocyte proliferation [68]. What is interesting in this study was that DCs treated with primed neutrophil supernatant-that collected following IL-8 priming and albumin-induced degranulation-also induced an increase in Treg in a TGF- $\beta$-dependent fashion. Likewise, elastase-and, more generally, supernatant from sputum isolated from patients with chronic obstructive pulmonary disease and Cystic Fibrosis-suppressed the DC expression of costimulatory markers, the latter in an elastase-dependent manner [70]. It remains to be explained how elastase can suppress DC responses and induce regulatory $\mathrm{T}$ cells, when in these contexts-sputum, or whole neutrophil supernatant-it is present alongside so many proinflammatory mediators.

However, two pieces of work do suggest a proinflammatory role for elastase. IFN- $\gamma$ producing $\mathrm{T}$ cells specific for neutrophil elastase have been identified [71]. These T cells were shown to be present in $40-60 \%$ of healthy individuals without any history of autoimmune disease. In addition, Souwer and colleagues [72] show that elastase is required for the generation of Th17 responses, owing to its cleavage of DC-produced CXCL8 into a more potent form. How this paper fits into the literature on elastase is complicated; it is in agreement with the proinflammatory nature of NETs, which contain elastase (see Section 4.2 'NETosis') but not with the previous research using elastase in isolation. This incongruence may be a result of the populations of $\mathrm{T}$ cells being used in this paper being highly pure, something that is often not the case with older studies.

4.1.4. Cathelicidin LL-37. The cathelicidin LL-37 is a $4 \mathrm{kDa}$ cationic amphipathic peptide stored in secondary granules as the inactive precursor hCAP- 18 before being cleaved by proteinase 3 during degranulation. Although it has long been known as a powerful antimicrobial, antifungal, and antiviral agent, now we also recognise its profound immunomodulatory roles.

Cathelicidin is one of the granule peptides most investigated for its role in adaptive immunity, with many influences on DC and T cells described. Interestingly, and reflecting data seen with MPO and elastase, results are split between pro- and anti-inflammatory outcomes (see Table 1), suggesting either concentration-dependent effects or that it acts in concert with other local mediators to produce dichotomous results. During inflammatory disease, LL-37-specific T cells exist; up to $75 \%$ of patients with severe psoriasis have $\mathrm{T}$ cells recognising LL-37, and these T cells are pathogenic and produce proinflammatory cytokines [73]. T cells from patients with psoriasis proliferate and produce IFN- $\gamma$ in response to ex vivo LL-37 exposure, while T cells from healthy control donors do not. Interestingly, LL-37-specific T cells were seen 
more frequently in patients with severe disease than with mild clinical scores. A different study [74] showed increased proliferation in healthy control $\mathrm{CD}^{+} \mathrm{T}$ cells with LL-37 exposure-this occurred in the presence and absence of DCs. Similarly, delivery of murine cathelicidin (mCRAMP) to $A p o E^{-/-}$mice induced activated degranulating $\mathrm{CD}^{+} \mathrm{T}$ cells with increased proliferation and IFN $-\gamma$ production [75]. $\mathrm{CD}^{+}{ }^{+}$T cells migrate towards LL-37 $[76,77]$ and whole peripheral blood leukocytes towards murine cathelin-related antimicrobial peptide (CRAMP) [78] in a dose-dependent fashion, but interestingly $\mathrm{CD} 8^{+} \mathrm{T}$ cells do not [77].

LL-37 can bind DCs directly (a review of the peptide's receptors is included in [79]), inducing maturation and CD86 expression on DCs [80]; this subsequently primes Th1 responses and induces the production of IFN $-\gamma$. This occurs via binding to the $\mathrm{G}$ protein-coupled receptor FPR2 [81].

A prominent role of LL-37 is to form complexes with self-DNA and allow its take up by plasmacytoid DC (pDC). LL-37-DNA complexes move into the endocytic pathway of the DC and therefore promote a strong IFN- $\alpha$ response [82]; this pDC type 1 interferon production then matures cDC and leads to pathogenic proliferation and activation of Th1 cells [83]. The same phenomenon-LL-37-facilitated priming of $\mathrm{pDC}$ - is seen with bacterial DNA and $\mathrm{CpG}$, allowing rapid responses to microbes [84]. Coexposure to LL-37 and CpG DNA induced the expression of costimulatory molecules CD86 and CD40 and production of IL-6 within five-minute exposure; this was specific, as T cells did not respond to CpG-LL-37 complexes.

In vivo, injection of CRAMP alongside OVA led to an enhancement of immune responses-proliferation of splenocytes, IL-4, IL-6, IL-10, and IFN- $\gamma$ production-without skewing of responses [78]. Finally, the proinflammatory role of LL-37 has been targeted in cancer therapy. In a model of mice challenged with SP2/0-CSFRj6-1 tumour cells, LL-37 enhanced vaccination with a DNA vaccine against M-CSFRj6-1. Addition of LL-37 to the vaccine improved the cytotoxic $\mathrm{T}$ cell response, IFN- $\gamma$, and IL- 4 production and resulted in prolonged survival [85]. In summary, therefore, there are a number of profoundly proinflammatory outcomes following LL-37's interaction with DC and T cells.

One intriguing study shows that LL-37 is not uniformly proinflammatory but is more discriminating in its immunomodulation. Nijnik et al. [86] showed that LL-37 inhibited IFN- $\gamma$-induced priming of DC, monocytes, and macrophages, abolishing TNF production following IFN- $\gamma$ exposure. In combination with IFN- $\gamma$, LL-37 suppressed TNF production following LTA stimulation but not that resulting from Pam3Csk4, flagellin, or NOD2.

Similarly, an increasing body of literature shows LL-37 can also be selectively anti-inflammatory. It specifically inhibits TLR4 ligand signalling in DCs, with no effect on TLR2 signalling [87]. This, in the context of a murine model of allergic contact dermatitis, means that LL-37 has an anti-inflammatory role. In this paper, LL-37 prevented the DC production of IL-6, IL-8, IL-10, and TNF following LPS treatment, but not IL- $1 \beta$ or GMCSF; this was via prevention of aggregation of the membrane receptor complex required for signal transduction.
Human DC react similarly to mouse; LL-37 inhibits monocyte-derived DC priming by LPS and subsequent stimulation of T cell proliferation [88]. IL-6 and TNF were totally inhibited by a physiologically relevant dose of LL-37. However, in this study, the signalling by TLR2 and TLR5 ligands (LTA and flagellin) was also inhibited by LL-37.

Direct effects on murine $\mathrm{T}$ cells show that it may induce apoptosis of certain cells $[89,90]$, in particular $\mathrm{T}$ regulatory cells and cytotoxic $\mathrm{CD}^{+} \mathrm{T}$ cells, which are significantly more sensitive to LL-37 than $\mathrm{CD}^{+}$cells. However, doses of LL-37 used in these studies were high (up to $100 \mu \mathrm{g} / \mathrm{ml}$ ). Murine cathelicidin (mCRAMP) also prevents the development of Th2 responses in vitro; isolated $\mathrm{T}$ cells from mice lacking cathelicidin overexpress Th2 in vitro while Th1 responses are normal [91].

4.1.5. Lactoferrin. Lactoferrin is an $80 \mathrm{kDa}$ protein from the transferrin family present alongside LL-37 in the secondary granules of neutrophils; it is abundant in milk and has strong antimicrobial activity.

When immature human DCs are incubated with lactoferrin, it induces an increase in maturation (CD83), activation (CD80, CD86), proinflammatory cytokine production (with discrepancies between reports), and CCR7 expression (resulting in migration towards CCL21) [92-94]. Consequently, $\mathrm{T}$ regulatory cell development is decreased and Th1 cells enhanced. These effects on DC required TLR2 and TLR4 signalling [93].

Used as an adjuvant during sheep red blood cell induced delayed type hypersensitivity, lactoferrin enhances inflammation and increases TNF, IL-10, and MIP $1 \alpha$ production by total peritoneal cells [95], with subsequent increased lymphocyte proliferation. This is however using a very high dose $(>50 \mu \mathrm{g} / \mathrm{ml})$.

Interest in using bovine lactoferrin as an adjuvant led to its use alongside Mycobacterium bovis Calmette-Guerin (BCG). BCG-infected DCs which had been exposed to lactoferrin showed an increase in activation and costimulation markers and increased stimulation of Th1 cells [96]. Use in this system led to a substantial increase in $\mathrm{CD} 4^{+}$splenic $\mathrm{T}$ cells producing IFN- $\gamma$ [97] compared to BCG alone, ultimately leading to a reduction in Mycobacterium tuberculosis-induced pathology [98].

Coculture of neutrophils and $\mathrm{CD}^{+}{ }^{+} \mathrm{T}$ cells results in the transfer of lactoferrin to the T cell surface [99]. Using the Jurkat cell line, lactoferrin was shown to induce tyrosine phosphorylation in the T cells 10 minutes after exposure; this upregulated CD4 expression through MAPK signalling, and potentially therefore CD3 complex signalling capability [100]. In mice expressing functional human lactoferrin, this boost to T cell signalling resulted in increased TNF and IFN- $\gamma$ production and improved bacterial clearance during Staphylococcus aureus infection [101]. Lactoferrin also has been shown to have positive impacts on $\mathrm{T}$ cell differentiation and maturation; it promotes CD4 expression and maturation of $\mathrm{CD}^{+}$cells from precursors and enhances proliferation $[102,103]$. Oral administration of bovine lactoferrin boosts $\mathrm{CD}^{+}$and $\mathrm{CD}^{+} \mathrm{T}$ cell numbers in the intestine [104]. Administration of lactoferrin following cyclophosphamide-mediated 
depletion restores T cell populations in mice [105]. Peripheral blood and splenic lymphocyte populations were significantly restored, particularly $\mathrm{CD} 4^{+} \mathrm{T}$ cells [105]. These interesting results, in toto, suggest that lactoferrin could be used to boost $\mathrm{CD}^{+}{ }^{+} \mathrm{T}$ cells in immunosuppressed individuals.

A truncated lactoferrin peptide comprising the first 11 residues from the $\mathrm{N}$-terminus, hLF1-11, is of interest as a novel antimicrobial. Exposure of differentiating DC to hLF1-11 increases their maturation and their ability to phagocytose Candida albicans and subsequently produce more IL-6 and less IL-12p40 [106]. This led to increased generation of Th17 cells.

Lactoferrin applied to pig small intestine mucosal explants [107] is rapidly taken up by lamina propria $\mathrm{T}$ cells, and administration of oral recombinant human lactoferrin results in the activation and proliferation of intestinal $\mathrm{T}$ cells [108], particularly $\mathrm{CD}^{+} \mathrm{T}$ cells which showed enhanced IFN- $\gamma$ production and improved responses to implanted tumours. However, lactoferrin has well-known antiinflammatory role in mouse and rat models of colitis [109, 110], and this appears to be a result of it decreasing Th1 and Th17 cells in the mesenteric lymph nodes and intestinal lamina propria and skewing towards $\mathrm{T}$ regulatory cells instead [111]. This may be a consequence of lactoferrin binding pathogen-associated molecular patterns (PAMPs) such as LPS and therefore dampening down immunity in the gut rather than directly acting on the T cells. However, the possibility remains that in the generally immunosuppressive environment of the intestinal mucosa, the signals generated in $\mathrm{T}$ cells by lactoferrin result in $\mathrm{T}$ regulatory cell development and suppression of immunopathology. The route of supply of lactoferrin also may have an impact, with single buccal dose and continual diet dosing increasing Th2 responses in the gut, while gastric intubation for delivery increased Th1 cytokine production [112].

Some other work has shown an inhibitory role of lactoferrin on $\mathrm{T}$ cell responses. It inhibits proliferation of $\mathrm{T}$ cells in an MLR [113] and inhibited proliferation and cytokine production of a Th1 cell line (but not Th2) [114]. Likewise, the transfer of lactoferrin to $\mathrm{CD}^{+} \mathrm{T}$ cells [99] induces suppression of IFN- $\gamma$ and enhancement of IL-10 in the activated T cells, suggesting this is another possible route of neutrophil-induced $\mathrm{T}$ cell regulation.

4.1.6. Arginase-1. Arginase-1 is present in the tertiary (gelatinase) granules; however, it is inactive at physiological $\mathrm{pH}$ unless activated by factors released by primary granule release [115]. Once released, it converts arginine to L-ornithine; as arginine is required for the expression of the $\mathrm{T}$ cell receptor zeta chain and subsequent proliferation of $\mathrm{T}$ cells $[116,117]$, the depletion of arginine results in cell cycle arrest and suppression of $\mathrm{T}$ cell responses; this is also mediated via an inability to upregulate cyclin D3 [118]. In addition, arginine is necessary for the dephosphorylation of cofilin, which stabilises the immunological synapse which forms between T cells and DC; arginase therefore destabilises the synapse and prevents adequate $\mathrm{T}$ cell activation $[119,120]$.
Arginase release from neutrophils is uniformly suppressive to $\mathrm{T}$ cell responses, unlike the more nuanced results for other granule mediators.

In addition to infection and sites of purulent inflammation [117], this suppression of $\mathrm{T}$ cell responses via arginase release occurs during pregnancy; neonatal neutrophils have higher arginase content and are more suppressive than adult neutrophils [121]. This is an intriguing explanation proposed for why newborns are susceptible to infection. Activated neutrophils are also present in the spleen of poststroke mice [122], and these produce arginase, resulting in suppressed $\mathrm{T}$ cells as a consequence of decreased CD3 zeta; similarly, neutrophils from airway neutrophils isolated from patients with Cystic Fibrosis suppress T cell activation via arginase [123].

Myeloid-derived suppressor cells produce arginase, which is one of the most prominent explanations for their suppressive activity; however, much of the research described above did not unpick relative contributions of MDSC and suppressive neutrophil activities or which subsets of neutrophils were involved (see Section 5 - a note on immature and low-density neutrophils).

4.1.7. Gelatinase. Gelatinase, a $94 \mathrm{kDa}$ type IV collagenase [124], is present in the tertiary granules of neutrophils. Research into the effects of gelatinase on $\mathrm{T}$ cell responses has not been examined in detail. However, recently, it has been shown that gelatinase released from neutrophils is indispensable for the generation of contact hypersensitivity responses [125]. In this interesting paper, neutrophil depletion reduced DC migration into the site of sensitization (the ear) and subsequent allergen-specific $\mathrm{T}$ cell priming and Th1 development. This is intriguing as gelatinase and arginase are released from the same granules but appear to have opposite impacts on adaptive immunity.

4.1.8. Cathepsin G. Cathepsin $G$ is a member of the serine protease family and is predominantly found in primary neutrophil granules, although it has also been detected in various myeloid cells and APCs [126, 127].

Cathepsin $G$ can serve as a signal that amplifies the inflammatory response. For example, it can act as a chemoattractant for neutrophils and monocytes [128]. Wittamer et al. revealed a role for cathepsin $\mathrm{G}$ in the processing and maturation of chemerin, a chemoattractant that specifically attracts APCs [129]. In addition, it is responsible for the quantum proteolytic processing of CXCL5 and CCL15 in to more potent chemotactic factors [130].

Cathepsin $\mathrm{G}$ is capable of binding to human lymphocytes and acting as a chemokinetic stimulant of T cells [128, 131]. The administration of cathepsin $\mathrm{G}$ in mice, together with antigen, enhances the antibody response and increases IFN $\gamma$ and IL-4 production [132]. Furthermore, cathepsin G plays a critical role in proinsulin processing and the activation of diabetogenic T cells [133]. The downregulation of cathepsin $G$ by specific inhibitors or siRNA was shown to mitigate the activation of $\mathrm{CD}^{+} \mathrm{T}$ cells in nonobese diabetic (NOD) mice, leading to reduced blood glucose and improved function of islet $\beta$ cells [134]. 
However, cathepsin $\mathrm{G}$ has also been implicated in the regulation of excessive inflammation. For instance, it can cleave the IL-1-related alarmins IL-18 and IL-33, as well as IL-15, which is important for both T cell and NK cell homeostasis [135]. In addition, cathepsin $G$ has been shown to disrupt CCL5 and CCL3 chemokine gradients, both of which recruit T lymphocytes $[136,137]$. It also reduces the bioactivity of the T cell-stimulating cytokines IL- 2 and IL- 6 at sites of inflammation and catalyzes the shedding of their receptors, thereby enhancing its suppressive effects [138].

In Cystic Fibrosis patients, cathepsin G can cleave the surface antigens $\mathrm{CD} 2, \mathrm{CD} 4$, and $\mathrm{CD} 8$, resulting in a temporary functional impairment of $\mathrm{T}$ lymphocytes and a state of immunological unresponsiveness in inflammatory foci [139]. Kish et al. also recently showed that during hapten skin sensitization, neutrophil cathepsin G inhibits the production of IL-12 from hapten-presenting DCs. This in turn suppresses the development of hapten-reactive $\mathrm{CD}^{+} \mathrm{T}$ cells and their differentiation in to IFN $\gamma$-producing effector cells [140].

4.1.9. Cathepsin D. Cathepsin D is an aspartyl protease, ubiquitously distributed in lysosomes. It has been implicated in a wide variety of biological processes, including proteolytic degradation and apoptosis, as well as various inflammatory disorders.

Cathepsin D has been suggested to play an essential role in tissue homeostasis. For example, it is required for the survival of mice beyond 4 weeks [141]. Mice deficient for this enzyme exhibited progressive atrophy of the intestinal mucosa and profound destruction of the lymphoid organs and cells [141]. Moreover, ceramide activates lysosomal cathepsin D (and B) to attenuate autophagy and induce ER stress to suppress myeloid-derived suppressor cells [142].

Cathepsin D is also involved in class II MHC-restricted antigen processing and the generation of $\mathrm{T}$ cell epitopes. This was first shown in 1994 when M. van Noort demonstrated that cathepsin D could induce the release of T cell stimulatory fragments from hen egg white lysozyme (HEL) in vitro. Cathepsin $\mathrm{D}$ has since been implicated in the proteolytic processing of thyroglobulin, myoglobulin, and tetanus toxin [143-145]. While not in neutrophils, DC cathepsin D is required for lipid antigen presentation by DCs: ligand activation of PPARg (Peroxisome Proliferator-Activated Receptor g) upregulates cathepsin D, which in turn generates the mature form of saposins, lipid transfer molecules that facilitate lipid loading to CD1d molecules [146].

On the other hand, cathepsin $\mathrm{D}$ has also been implicated in apoptosis and the resolution of innate immune responses. Caspase 8 is directly activated by cathepsin $\mathrm{D}$, which in turn triggers a proapoptotic pathway in neutrophils. Inactivation of cathepsin $\mathrm{D}$ by both genetic and pharmacological means delayed neutrophil apoptosis and prolonged the inflammatory response to LPS in vivo [147]. Bidere et al. also demonstrated that cathepsin $\mathrm{D}$ triggers a rapid conformational change in Bax upon apoptotic signalling. This induces the release of mitochondrial apoptosis-inducing factor (AIF), which controls the early apoptotic phenotype in activated T lymphocytes [148].

4.2. NETosis. Neutrophils release extracellular fibres known as neutrophil extracellular traps (NETs, [7]). NETs comprise cytoplasmic and granule proteins bound to a web of chromatin, and their expulsion encapsulates and kills microbes. Notably, murine neutrophils produce NETs more slowly and less efficiently than human neutrophils; however, these differences could be attributed to murine neutrophils being isolated from the bone marrow, while human neutrophils are peripherally derived [149].

NETosis can be triggered by a wide range of stimuli including, in vitro, biochemical agents, pathogens (for example, Staphylococcus aureus), and their products (for example, LPS), although PMA (phorbol 12-myristate 13-acetate) is used most often as it potently induces NETting in all studies [150-152].

Neutrophil products, including granule contents, embedded within NETs can cause host tissue damage and disease [153]. The first study to describe NETs analysed their composition using immunofluorescence and noted DNA, histones, neutrophil elastase (NE), cathepsin G, myeloperoxidase (MPO), lactoferrin, and gelatinase [7]. This suggested a network of DNA decorated with many granule proteins. A more recent proteomic approach analysing PMA-induced NETs identified 24 NET-associated proteins, including granule proteins in addition to cytoplasmic proteins such as calprotectin, and cytoskeletal proteins actin $\beta / \gamma$ [154]; the most abundant nonhistone protein was NE. Of importance for interpretation, the proteomic analysis did not find previously described NET-associated proteins $\mathrm{H1}$, BPI, cathelicidin (hCAP-18), and pentraxin 3 (PTX-3). Subsequent immunoblot analysis established the presence of BPI, but not of PTX-3 or hCAP-18. They propose that these proteins perhaps are loosely attached to NETs and therefore were lost during the isolation procedure [154]. It has also been suggested that different stimulants can induce varying NET composition.

Many NET experiments are performed following induction of NETosis with PMA, which also profoundly activates $\mathrm{T}$ cells. Although attempts are made to wash NETs and control for this, it must be borne in mind when interpreting the impact of NETs on adaptive immunity. New methods of inducing NETs without PMA [151] are now defined, and use of these will allow confirmation of current results.

The presence of antimicrobial peptides in the NET structure licences the DNA to become immunomodulatory and to activate DCs. NETs stably interact with DCs, unlike apoptotic or live neutrophils [155], and the DCs take up NET components, notably proteinase 3 and myeloperoxidase. NETs induce type one interferon production by pDCs, a first step to autoimmunity [156], and promote Th1 responses in the mouse model collagen-induced arthritis [157] through enhancing DC maturation and costimulation. In the rheumatoid joint, NETs containing citrullinated peptides are taken up by fibroblasts, which then present NET peptides to local T cells [158]; this leads to damage of local cartilage and development of autoimmune populations of $\mathrm{T}$ cells. NET fragments (following digestion with DNAse) induce CD40, 
CD80, CD86, and MHC II upregulation on mouse bone marrow-derived DCs via TLR-MyD88 signalling [159]; this led to proliferation of allogeneic $\mathrm{CD}^{+} \mathrm{T}$ cells. This is important as DNAse is suggested as a therapy for many diseases and is approved for use in Cystic Fibrosis. NETs are triggered by cigarette smoke, and these drive $\mathrm{pDC}$ maturation and activation [160]. NETs and cigarette smoke extract together induced pDC to upregulate CD40, CD86, and MHC II and to produce IFN- $\alpha$, IL-6, and IL- $12 \mathrm{p} 70$. As a result, these $\mathrm{pDCs}$ produced more inflammatory cytokines (IFN- $\gamma$ and IL-17), consequent to increased Tbet and ROR $\gamma$ t, than $\mathrm{pDC}$ exposed to air control. This is proposed to be one way in which inflammatory responses are generated and maintained in COPD.

NETs are released by patients with SLE complex self DNA and the granule peptides LL-37 and HNPs; these NET-DNA complexes triggered TLR9 and promoted pathogenic type 1 IFN release [161].

In addition to priming DCs, NETs can act directly on $\mathrm{CD} 4^{+} \mathrm{T}$ cells. Human T cells reacted to NETs by increased phosphorylation of the tyrosine kinase ZAP70, which is critical for downstream $\mathrm{T}$ cell activation [162]. This led to increased expression of the activation markers CD25 and CD69. Mechanistically, it appears that the presence of NETs primes $\mathrm{CD}^{+} \mathrm{T}$ cells so that they are able to respond to and proliferate following the presentation of low doses of antigen, even in the absence of costimulation. NETs-and neutrophils in general-are most frequently associated with Th17 responses in local $\mathrm{T}$ cells, but they can also induce Th2 responses. Recently it has been shown that NETs induced in the lung following rhinovirus infection promote type 2 immunity and exacerbations of asthma [163].

$\mathrm{HIV}$ or SIV-infected individuals overproduce NETs. It is suggested that these NETs trap and induce apoptosis in $\mathrm{CD}^{+}$and $\mathrm{CD}^{+} \mathrm{T}$ cells and that this may be one mechanism by which these $\mathrm{T}$ cells are lost during infection [164].

In summary, NETs are highly proinflammatory for DC and $\mathrm{T}$ cell responses, and the granule peptides coating these NET strands play a large part in this, despite their frequent anti-inflammatory roles when used in isolation. It is possible that increased concentration on the strands licences proinflammatory roles, that the particular combination of proteins acts in concert with unexpected outcomes for $\mathrm{T}$ cells, or that the presence of DNA tips the balance from anti- to proinflammatory.

Intriguingly, a regulatory role for NETs is shown in [165]. This paper exposed monocyte-derived DC to human NETs and showed how this downregulated LPS-induced maturation, cytokine production, and costimulatory molecule expression. Unsurprisingly, this had the consequence of reducing subsequent $\mathrm{CD}^{+} \mathrm{T}$ cell proliferation [165]. In this paper, NET fragments were induced and isolated with A23187 stimulation then Alu1 restriction enzyme treatment. It is possible that differences in outcome from published NET papers reflect the methods of isolation.

Finally, it is worth noting that not only NETs released by neutrophils impact the adaptive immune response; the cell bodies, cytoplasts, left behind following NETosis are also capable of doing so. In asthma, it has been shown that these cytoplasts were present in draining lymph nodes and induced
DC to promote Th17 generation [166]. This exciting paper opens up a whole new area of research as we consider how neutrophils can affect $\mathrm{T}$ cells in lymph nodes.

\section{A Note on Immature and Low-Density Neutrophils and Myeloid-Derived Suppressor Cells}

Isolation of neutrophils using density gradients can allow some neutrophils to come out in the isolated PBMC layer; these low-density neutrophils impair $\mathrm{T}$ cell proliferation in vitro and may represent granulocytic myeloid-derived suppressor cells (MDSC), although the low-density layer may also include more than one population $[167,168]$. It is not currently possible to fully distinguish myeloid-derived suppressor cells from mature neutrophils [32], both being CD14- CD15+ CD11b+ CD66b+ HLADR- [32]. Furthermore, many of the studies in this review were performed before the era of MDSC, and as such it is not possible to unpick relative impacts of MDSC vs. activatory neutrophils in each case.

Recently, CD10 has been identified as a marker which discriminates between mature (CD10+) and immature (CD10-) neutrophils, with the former inhibiting $\mathrm{T}$ cells via arginase-1 and the latter promoting T cell proliferation and IFN- $\gamma$ production [168]. Increasing the use of this marker in flow cytometry panels may enable discrimination of these subsets and examination of their impact during inflammatory disease. It remains an intriguing possibility that the dichotomous results presented at the beginning of this article, from in vitro and in vivo experiments over many decades, may include results from soon-to-be clearly delineated subsets of cells-and that we may soon be able to examine them with fresh eyes.

Overall, what this means is that it is essential for researchers to examine and present neutrophil maturation status and gross phenotype clearly, as well as clearly describing isolation methods used, so that readers are in full knowledge of the facts.

Finally, neutrophils can interact with Dynabead-style activation beads which are commonly used to activate $\mathrm{T}$ cells [167], leading to suppression of $\mathrm{T}$ cell proliferation in vitro which does not reflect in vivo situations. This must be considered when reflecting on published data.

\section{Conflicts of Interest}

The authors declare that no conflict of interest exists.

\section{Authors' Contributions}

Danielle Minns and Katie Jane Smith contributed equally to this work.

\section{Acknowledgments}

EGF and DM are funded by a Royal Society Dorothy Hodgkin Fellowship to EGF (DH150175); EGF and KS are funded by a Royal Society Research Fellows Enhancement Award to EGF (180049). 


\section{References}

[1] M. A. Cassatella, "The production of cytokines by polymorphonuclear neutrophils," Immunology Today, vol. 16, no. 1, pp. 21-26, 1995.

[2] Y. V. Subrahmanyam, S. Yamaga, Y. Prashar et al., "RNA expression patterns change dramatically in human neutrophils exposed to bacteria," Blood, vol.97, no. 8, pp. 2457-2468, 2001.

[3] M. Casanova-Acebes, C. Pitaval, L. A. Weiss et al., "Rhythmic modulation of the hematopoietic niche through neutrophil clearance," Cell, vol. 153, no. 5, pp. 1025-1035, 2013.

[4] J. Pillay, I. den Braber, N. Vrisekoop et al., "In vivo labeling with ${ }^{2} \mathrm{H}_{2} \mathrm{O}$ reveals a human neutrophil lifespan of 5.4 days," Blood, vol. 116, no. 4, pp. 625-627, 2010.

[5] K. Lim, Y. M. Hyun, K. Lambert-Emo et al., "Neutrophil trails guide influenza-specific $\mathrm{CD}^{+} \mathrm{T}$ cells in the airways," Science, vol. 349, no. 6252, article aaa4352, 2015.

[6] J. Lv, D. Wang, Y. H. Hua et al., "Pulmonary immune responses to 2009 pandemic influenza A (H1N1) virus in mice," BMC Infectious Diseases, vol. 14, no. 1, p. 197, 2014.

[7] V. Brinkmann, U. Reichard, C. Goosmann et al., "Neutrophil extracellular traps kill bacteria," Science, vol. 303, no. 5663, pp. 1532-1535, 2004.

[8] T. Tak, T. P. Rygiel, G. Karnam et al., "Neutrophil-mediated suppression of influenza-induced pathology requires CD11b/CD18 (MAC-1)," American Journal of Respiratory Cell and Molecular Biology, vol. 58, no. 4, pp. 492-499, 2018.

[9] C.-W. Yang, B. S. I. Strong, M. J. Miller, and E. R. Unanue, "Neutrophils influence the level of antigen presentation during the immune response to protein antigens in adjuvants," The Journal of Immunology, vol. 185, no. 5, pp. 2927-2934, 2010.

[10] J. Pillay, V. M. Kamp, E. van Hoffen et al., "A subset of neutrophils in human systemic inflammation inhibits $\mathrm{T}$ cell responses through Mac-1," The Journal of Clinical Investigation, vol. 122, no. 1, pp. 327-336, 2012.

[11] M. Thewissen, J. Damoiseaux, J. van de Gaar, and J. W. C. Tervaert, "Neutrophils and T cells: bidirectional effects and functional interferences," Molecular Immunology, vol. 48, no. 15-16, pp. 2094-2101, 2011.

[12] A. R. Clayton, R. L. Prue, L. Harper, M. T. Drayson, and C. O. S. Savage, "Dendritic cell uptake of human apoptotic and necrotic neutrophils inhibits CD40, CD80, and CD86 expression and reduces allogeneic $\mathrm{T}$ cell responses: relevance to systemic vasculitis," Arthritis \& Rheumatism, vol. 48, no. 8, pp. 2362-2374, 2003.

[13] F. L. Ribeiro-Gomes, N. C. Peters, A. Debrabant, and D. L. Sacks, "Efficient capture of infected neutrophils by dendritic cells in the skin inhibits the early anti-leishmania response," PLoS Pathogens, vol. 8, no. 2, article e1002536, 2012.

[14] C. Morel, E. Badell, V. Abadie et al., "Mycobacterium bovis BCG-infected neutrophils and dendritic cells cooperate to induce specific T cell responses in humans and mice," European Journal of Immunology, vol. 38, no. 2, pp. 437-447, 2008.

[15] S. J. Park, M. D. Burdick, and B. Mehrad, "Neutrophils mediate maturation and efflux of lung dendritic cells in response to Aspergillus fumigatus germ tubes," Infection and Immunity, vol. 80, no. 5, pp. 1759-1765, 2012.

[16] S. Schuster, B. Hurrell, and F. Tacchini-Cottier, "Crosstalk between neutrophils and dendritic cells: a context-dependent process," Journal of Leukocyte Biology, vol. 94, no. 4, pp. 671$675,2013$.

[17] A. M. Megiovanni, F. Sanchez, M. Robledo-Sarmiento, C. Morel, J. C. Gluckman, and S. Boudaly, "Polymorphonuclear neutrophils deliver activation signals and antigenic molecules to dendritic cells: a new link between leukocytes upstream of T lymphocytes," Journal of Leukocyte Biology, vol. 79, no. 5, pp. 977-988, 2006.

[18] S. Bennouna, S. K. Bliss, T. J. Curiel, and E. Y. Denkers, "Cross-talk in the innate immune system: neutrophils instruct recruitment and activation of dendritic cells during microbial infection," The Journal of Immunology, vol. 171, no. 11, pp. 6052-6058, 2003.

[19] S. Bennouna and E. Y. Denkers, "Microbial antigen triggers rapid mobilization of TNF- $\alpha$ to the surface of mouse neutrophils transforming them into inducers of high-level dendritic cell TNF- $\alpha$ production," The Journal of Immunology, vol. 174, no. 8, pp. 4845-4851, 2005.

[20] K. Steinbach, M. Piedavent, S. Bauer, J. T. Neumann, and M. A. Friese, "Neutrophils amplify autoimmune central nervous system infiltrates by maturing local APCs," The Journal of Immunology, vol. 191, no. 9, pp. 4531-4539, 2013.

[21] K. P. J. M. van Gisbergen, M. Sanchez-Hernandez, T. B. H. Geijtenbeek, and Y. van Kooyk, "Neutrophils mediate immune modulation of dendritic cells through glycosylation-dependent interactions between Mac-1 and DC-SIGN," The Journal of Experimental Medicine, vol. 201, no. 8, pp. 1281-1292, 2005.

[22] R. Blomgran and J. D. Ernst, "Lung neutrophils facilitate activation of naive antigen-specific $\mathrm{CD} 4{ }^{+} \mathrm{T}$ cells during $\mathrm{Myco-}$ bacterium tuberculosis infection," The Journal of Immunology, vol. 186, no. 12, pp. 7110-7119, 2011.

[23] M. Charmoy, S. Brunner-Agten, D. Aebischer et al., "Neutrophil-derived CCL3 is essential for the rapid recruitment of dendritic cells to the site of Leishmania major inoculation in resistant mice," PLoS Pathogens, vol. 6, no. 2, article e1000755, 2010.

[24] M. D. Tate, A. G. Brooks, P. C. Reading, and J. D. Mintern, "Neutrophils sustain effective $\mathrm{CD} 8^{+} \mathrm{T}$-cell responses in the respiratory tract following influenza infection," Immunology and Cell Biology, vol. 90, no. 2, pp. 197-205, 2012.

[25] L. Romani, A. Mencacci, E. Cenci et al., "Neutrophil production of IL-12 and IL-10 in candidiasis and efficacy of IL-12 therapy in neutropenic mice," The Journal of Immunology, vol. 158, no. 11, pp. 5349-5356, 1997.

[26] K. Tateda, T. A. Moore, J. C. Deng et al., "Early recruitment of neutrophils determines subsequent T1/T2 host responses in a murine model of Legionella pneumophila pneumonia," The Journal of Immunology, vol. 166, no. 5, pp. 3355-3361, 2001.

[27] M. Radsak, C. Iking-Konert, S. Stegmaier, K. Andrassy, and G. M. Hansch, "Polymorphonuclear neutrophils as accessory cells for T-cell activation: major histocompatibility complex class II restricted antigen-dependent induction of T-cell proliferation," Immunology, vol. 101, no. 4, pp. 521-530, 2000.

[28] N. A. Fanger, C. Liu, P. M. Guyre et al., "Activation of human T cells by major histocompatability complex class II expressing neutrophils: proliferation in the presence of superantigen, but not tetanus toxoid," Blood, vol. 89, no. 11, pp. 4128-4135, 1997.

[29] N. S. Potter and C. V. Harding, "Neutrophils process exogenous bacteria via an alternate class I MHC processing 
pathway for presentation of peptides to T lymphocytes," The Journal of Immunology, vol. 167, no. 5, pp. 2538-2546, 2001.

[30] S. Culshaw, O. R. Millington, J. M. Brewer, and I. B. McInnes, "Murine neutrophils present class II restricted antigen," Immunology Letters, vol. 118, no. 1, pp. 49-54, 2008.

[31] C. Beauvillain, Y. Delneste, M. Scotet et al., "Neutrophils efficiently cross-prime naive T cells in vivo," Blood, vol. 110, no. 8, pp. 2965-2973, 2007.

[32] C. Rosales, "Neutrophil: a cell with many roles in inflammation or several cell types?," Frontiers in Physiology, vol. 9, p. 113, 2018.

[33] R. Mazor, R. Shurtz-Swirski, R. Farah et al., "Primed polymorphonuclear leukocytes constitute a possible link between inflammation and oxidative stress in hyperlipidemic patients," Atherosclerosis, vol. 197, no. 2, pp. 937-943, 2008.

[34] C. Silvestre-Roig, A. Hidalgo, and O. Soehnlein, "Neutrophil heterogeneity: implications for homeostasis and pathogenesis," Blood, vol. 127, no. 18, pp. 2173-2181, 2016.

[35] E. B. Eruslanov, S. Singhal, and S. M. Albelda, "Mouse versus human neutrophils in cancer: a major knowledge gap," Trends in Cancer, vol. 3, no. 2, pp. 149-160, 2017.

[36] P. M. Henson, B. Zanolari, N. A. Schwartzman, and S. R. Hong, "Intracellular control of human neutrophil secretion. I. C5a-induced stimulus-specific desensitization and the effects of cytochalasin B," The Journal of Immunology, vol. 121, no. 3, pp. 851-855, 1978.

[37] H. Sengelov, P. Follin, L. Kjeldsen, K. Lollike, C. Dahlgren, and N. Borregaard, "Mobilization of granules and secretory vesicles during in vivo exudation of human neutrophils," The Journal of Immunology, vol. 154, no. 8, pp. 4157-4165, 1995.

[38] I. Naegelen, N. Beaume, S. Plancon, V. Schenten, E. J. Tschirhart, and S. Brechard, "Regulation of neutrophil degranulation and cytokine secretion: a novel model approach based on linear fitting," Journal of Immunology Research, vol. 2015, Article ID 817038, 15 pages, 2015.

[39] A. Sheshachalam, N. Srivastava, T. Mitchell, P. Lacy, and G. Eitzen, "Granule protein processing and regulated secretion in neutrophils," Frontiers in Immunology, vol. 5, p. $448,2014$.

[40] V. Le Cabec, J. B. Cowland, J. Calafat, and N. Borregaard, “Targeting of proteins to granule subsets is determined by timing and not by sorting: the specific granule protein NGAL is localized to azurophil granules when expressed in HL-60 cells," Proceedings of the National Academy of Sciences of the United States of America, vol. 93, no. 13, pp. 6454-6457, 1996.

[41] J. B. Cowland and N. Borregaard, "Granulopoiesis and granules of human neutrophils," Immunological Reviews, vol. 273, no. 1, pp. 11-28, 2016.

[42] M. Faurschou and N. Borregaard, "Neutrophil granules and secretory vesicles in inflammation," Microbes and Infection, vol. 5, no. 14, pp. 1317-1327, 2003.

[43] G. Lominadze, D. W. Powell, G. C. Luerman, A. J. Link, R. A. Ward, and K. R. McLeish, "Proteomic analysis of human neutrophil granules," Molecular \& Cellular Proteomics, vol. 4, no. 10, pp. 1503-1521, 2005.

[44] S. Rørvig, O. Østergaard, N. H. H. Heegaard, and N. Borregaard, "Proteome profiling of human neutrophil granule subsets, secretory vesicles, and cell membrane: correlation with transcriptome profiling of neutrophil precursors," Journal of Leukocyte Biology, vol. 94, no. 4, pp. 711-721, 2013.
[45] Y. Aratani, "Myeloperoxidase: its role for host defense, inflammation, and neutrophil function," Archives of Biochemistry and Biophysics, vol. 640, pp. 47-52, 2018.

[46] B. S. Rayner, D. T. Love, and C. L. Hawkins, "Comparative reactivity of myeloperoxidase-derived oxidants with mammalian cells," Free Radical Biology \& Medicine, vol. 71, pp. 240-255, 2014.

[47] M. E. Griffith, A. Coulthart, and C. D. Pusey, "T cell responses to myeloperoxidase (MPO) and proteinase 3 (PR3) in patients with systemic vasculitis," Clinical and Experimental Immunology, vol. 103, no. 2, pp. 253-258, 1996.

[48] J. D. Ooi, J. Chang, M. J. Hickey et al., “The immunodominant myeloperoxidase T-cell epitope induces local cell-mediated injury in antimyeloperoxidase glomerulonephritis," Proceedings of the National Academy of Sciences of the United States of America, vol. 109, no. 39, pp. E2615-E2624, 2012.

[49] P. Y. Gan, S. R. Holdsworth, A. R. Kitching, and J. D. Ooi, "Myeloperoxidase (MPO)-specific $\mathrm{CD}^{+}{ }^{+} \mathrm{T}$ cells contribute to MPO-anti-neutrophil cytoplasmic antibody (ANCA) associated glomerulonephritis," Cellular Immunology, vol. 282, no. 1, pp. 21-27, 2013.

[50] K. M. O’Sullivan, C. Y. Lo, S. A. Summers et al., "Renal participation of myeloperoxidase in antineutrophil cytoplasmic antibody (ANCA)-associated glomerulonephritis," Kidney International, vol. 88, no. 5, pp. 1030-1046, 2015.

[51] P. Y. Gan, O. M. Steinmetz, D. S. Y. Tan et al., "Th17 cells promote autoimmune anti-myeloperoxidase glomerulonephritis," Journal of the American Society of Nephrology, vol. 21, no. 6, pp. 925-931, 2010.

[52] D. Odobasic, A. R. Kitching, T. J. Semple, and S. R. Holdsworth, "Endogenous myeloperoxidase promotes neutrophil-mediated renal injury, but attenuates $\mathrm{T}$ cell immunity inducing crescentic glomerulonephritis," Journal of the American Society of Nephrology, vol. 18, no. 3, pp. 760-770, 2007.

[53] D. Odobasic, R. C. M. Muljadi, K. M. O'Sullivan et al., "Suppression of autoimmunity and renal disease in pristane-induced lupus by myeloperoxidase," Arthritis \& Rhematology, vol. 67, no. 7, pp. 1868-1880, 2015.

[54] E. Brouwer, C. A. Stegeman, M. G. Huitema, P. C. Limburg, and C. G. Kallenberg, "T cell reactivity to proteinase 3 and myeloperoxidase in patients with Wegener's granulomatosis (WG)," Clinical and Experimental Immunology, vol. 98, no. 3, pp. 448-453, 1994.

[55] D. Odobasic, A. R. Kitching, Y. Yang et al., "Neutrophil myeloperoxidase regulates T-cell-driven tissue inflammation in mice by inhibiting dendritic cell function," Blood, vol. 121, no. 20, pp. 4195-4204, 2013.

[56] J. Marcinkiewicz, B. Nowak, A. Grabowska, M. Bobek, L. Petrovska, and B. Chain, "Regulation of murine dendritic cell functions in vitro by taurine chloramine, a major product of the neutrophil myeloperoxidase-halide system," Immunology, vol. 98, no. 3, pp. 371-378, 1999.

[57] J. Marcinkiewicz, A. Grabowska, and B. M. Chain, "Modulation of antigen-specific T-cell activation in vitro by taurine chloramine," Immunology, vol. 94, no. 3, pp. 325-330, 1998.

[58] R. I. Lehrer and W. Lu, " $\alpha$-Defensins in human innate immunity,” Immunological Reviews, vol. 245, no. 1, pp. 84-112, 2012.

[59] O. Chertov, D. F. Michiel, L. Xu et al., "Identification of defensin-1, defensin-2, and CAP37/azurocidin as T-cell 
chemoattractant proteins released from interleukin-8-stimulated neutrophils," The Journal of Biological Chemistry, vol. 271, no. 6, pp. 2935-2940, 1996.

[60] J. Grigat, A. Soruri, U. Forssmann, J. Riggert, and J. Zwirner, "Chemoattraction of macrophages, T lymphocytes, and mast cells is evolutionarily conserved within the human $\alpha$-defensin family," The Journal of Immunology, vol. 179, no. 6, pp. 39583965, 2007.

[61] D. Yang, Q. Chen, O. Chertov, and J. J. Oppenheim, "Human neutrophil defensins selectively chemoattract naive $\mathrm{T}$ and immature dendritic cells," Journal of Leukocyte Biology, vol. 68, no. 1, pp. 9-14, 2000.

[62] R. Vaschetto, J. Grinstein, L. Del Sorbo et al., "Role of human neutrophil peptides in the initial interaction between lung epithelial cells and CD4+ lymphocytes," Journal of Leukocyte Biology, vol. 81, no. 4, pp. 1022-1031, 2007.

[63] F. Wang, L. Qiao, X. Lv et al., "Alarmin human $\alpha$ defensin HNP1 activates plasmacytoid dendritic cells by triggering NF- $\kappa \mathrm{B}$ and IRF1 signaling pathways," Cytokine, vol. 83, pp. 53-60, 2016.

[64] P. Presicce, S. Giannelli, A. Taddeo, M. L. Villa, and S. Della Bella, "Human defensins activate monocyte-derived dendritic cells, promote the production of proinflammatory cytokines, and up-regulate the surface expression of CD91," Journal of Leukocyte Biology, vol. 86, no. 4, pp. 941-948, 2009.

[65] M. Rodriguez-Garcia, H. Oliva, N. Climent et al., "Impact of $\alpha$-defensins1-3 on the maturation and differentiation of human monocyte-derived DCs. Concentration-dependent opposite dual effects," Clinical Immunology, vol. 131, no. 3, pp. 374-384, 2009.

[66] R. M. Rao, T. V. Betz, D. J. Lamont et al., "Elastase release by transmigrating neutrophils deactivates endothelial-bound SDF- $1 \alpha$ and attenuates subsequent $\mathrm{T}$ lymphocyte transendothelial migration," The Journal of Experimental Medicine, vol. 200, no. 6, pp. 713-724, 2004.

[67] H. Domon, K. Nagai, T. Maekawa et al., "Neutrophil elastase subverts the immune response by cleaving toll-like receptors and cytokines in pneumococcal pneumonia," Frontiers in Immunology, vol. 9, p. 732, 2018.

[68] P. C. Maffia, S. E. Zittermann, M. L. Scimone et al., "Neutrophil elastase converts human immature dendritic cells into transforming growth factor- $\beta 1$-secreting cells and reduces allostimulatory ability," The American Journal of Pathology, vol. 171, no. 3, pp. 928-937, 2007.

[69] N. L. Tateosian, R. M. Reiteri, N. O. Amiano et al., "Neutrophil elastase treated dendritic cells promote the generation of $\mathrm{CD}^{+}{ }^{+} \mathrm{FOXP} 3^{+}$regulatory T cells in vitro," Cellular Immunology, vol. 269, no. 2, pp. 128-134, 2011.

[70] A. Roghanian, E. M. Drost, W. MacNee, S. E. M. Howie, and J. M. Sallenave, "Inflammatory lung secretions inhibit dendritic cell maturation and function via neutrophil elastase," American Journal of Respiratory and Critical Care Medicine, vol. 174, no. 11, pp. 1189-1198, 2006.

[71] H. Fujiwara, F. El Ouriaghli, M. Grube et al., "Identification and in vitro expansion of $\mathrm{CD} 4^{+}$and $\mathrm{CD} 8^{+} \mathrm{T}$ cells specific for human neutrophil elastase," Blood, vol. 103, no. 8, pp. 3076-3083, 2004.

[72] Y. Souwer, T. Groot Kormelink, E. W. Taanman-Kueter et al., "Human $\mathrm{T}_{\mathrm{H}} 17$ cell development requires processing of dendritic cell-derived CXCL8 by neutrophil elastase," The Journal of Allergy and Clinical Immunology, vol. 141, no. 6, pp. 2286-2289.e5, 2018.
[73] R. Lande, E. Botti, C. Jandus et al., "The antimicrobial peptide LL37 is a T-cell autoantigen in psoriasis," Nature Communications, vol. 5, no. 1, p. 5621, 2014.

[74] R. Thomi, C. Schlapbach, N. Yawalkar, D. Simon, D. Yerly, and R. E. Hunger, "Elevated levels of the antimicrobial peptide LL-37 in hidradenitis suppurativa are associated with a Th1/Th17 immune response," Experimental Dermatology, vol. 27, no. 2, pp. 172-177, 2018.

[75] P. M. Mihailovic, W. M. Lio, J. Yano et al., "The cathelicidin protein CRAMP is a potential atherosclerosis self-antigen in ApoE(-/-) mice," PLoS One, vol. 12, no. 11, article e0187432, 2017.

[76] D. Yang, Q. Chen, A. P. Schmidt et al., "Ll-37, the neutrophil granule-and epithelial cell-derived cathelicidin, utilizes formyl peptide receptor-like 1 (Fprl1) as a receptor to chemoattract human peripheral blood neutrophils, monocytes, and T cells," The Journal of Experimental Medicine, vol. 192, no. 7, pp. 1069-1074, 2000.

[77] B. Agerberth, J. Charo, J. Werr et al., "The human antimicrobial and chemotactic peptides LL-37 and $\alpha$-defensins are expressed by specific lymphocyte and monocyte populations," Blood, vol. 96, no. 9, pp. 3086-3093, 2000.

[78] K. Kurosaka, Q. Chen, F. Yarovinsky, J. J. Oppenheim, and D. Yang, "Mouse cathelin-related antimicrobial peptide chemoattracts leukocytes using formyl peptide receptor-like $1 /$ mouse formyl peptide receptor-like 2 as the receptor and acts as an immune adjuvant," The Journal of Immunology, vol. 174, no. 10, pp. 6257-6265, 2005.

[79] D. Vandamme, B. Landuyt, W. Luyten, and L. Schoofs, “A comprehensive summary of LL-37, the factotum human cathelicidin peptide," Cellular Immunology, vol. 280, no. 1, pp. 22-35, 2012.

[80] D. J. Davidson, A. J. Currie, G. S. D. Reid et al., "The cationic antimicrobial peptide LL-37 modulates dendritic cell differentiation and dendritic cell-induced T cell polarization," The Journal of Immunology, vol. 172, no. 2, pp. 1146-1156, 2004.

[81] K. Chen, Y. Xiang, J. Huang et al., "The formylpeptide receptor 2 (Fpr2) and its endogenous ligand cathelin-related antimicrobial peptide (CRAMP) promote dendritic cell maturation," The Journal of Biological Chemistry, vol. 289, no. 25, pp. 17553-17563, 2014.

[82] R. Lande, J. Gregorio, V. Facchinetti et al., "Plasmacytoid dendritic cells sense self-DNA coupled with antimicrobial peptide," Nature, vol. 449, no. 7162, pp. 564-569, 2007.

[83] P. Blanco, A. K. Palucka, M. Gill, V. Pascual, and J. Banchereau, "Induction of dendritic cell differentiation by IFN- $\alpha$ in systemic lupus erythematosus," Science, vol. 294, no. 5546 , pp. $1540-1543,2001$.

[84] P. Hurtado and C. Au Peh, "LL-37 promotes rapid sensing of CpG oligodeoxynucleotides by B lymphocytes and plasmacytoid dendritic cells," The Journal of Immunology, vol. 184, no. 3, pp. 1425-1435, 2010.

[85] L. L. An, Y. H. Yang, X. T. Ma et al., "LL-37 enhances adaptive antitumor immune response in a murine model when genetically fused with ${\mathrm{M}-\mathrm{CSFR}_{\mathrm{J6}-1}} \mathrm{DNA}$ vaccine," Leukemia Research, vol. 29, no. 5, pp. 535-543, 2005.

[86] A. Nijnik, J. Pistolic, A. Wyatt, S. Tam, and R. E. W. Hancock, "Human cathelicidin peptide LL-37 modulates the effects of IFN- $\gamma$ on APCs," The Journal of Immunology, vol. 183, no. 9, pp. 5788-5798, 2009. 
[87] A. Di Nardo, M. H. Braff, K. R. Taylor et al., "Cathelicidin antimicrobial peptides block dendritic cell TLR4 activation and allergic contact sensitization," The Journal of Immunology, vol. 178, no. 3, pp. 1829-1834, 2007.

[88] K. Kandler, R. Shaykhiev, P. Kleemann et al., "The anti-microbial peptide LL-37 inhibits the activation of dendritic cells by TLR ligands," International Immunology, vol. 18, no. 12, pp. 1729-1736, 2006.

[89] J. S. Mader, M. Marcet-Palacios, R. E. W. Hancock, and R. C. Bleackley, "The human cathelicidin, LL-37, induces granzyme-mediated apoptosis in cytotoxic T lymphocytes," Experimental Cell Research, vol. 317, no. 4, pp. 531-538, 2011.

[90] J. S. Mader, C. Ewen, R. E. W. Hancock, and R. C. Bleackley, "The human cathelicidin, LL-37, induces granzyme-mediated apoptosis in regulatory T cells," Journal of Immunotherapy, vol. 34, no. 3, pp. 229-235, 2011.

[91] N. W. Kin, Y. Chen, E. K. Stefanov, R. L. Gallo, and J. F. Kearney, "Cathelin-related antimicrobial peptide differentially regulates T- and B-cell function," European Journal of Immunology, vol. 41, no. 10, pp. 3006-3016, 2011.

[92] M. Spadaro, C. Caorsi, P. Ceruti et al., "Lactoferrin, a major defense protein of innate immunity, is a novel maturation factor for human dendritic cells," The FASEB Journal, vol. 22, no. 8, pp. 2747-2757, 2008.

[93] M. Spadaro, M. Montone, M. Arigoni et al., "Recombinant human lactoferrin induces human and mouse dendritic cell maturation via toll-like receptors 2 and 4," The FASEB Journal, vol. 28, no. 1, pp. 416-429, 2014.

[94] G. de la Rosa, D. Yang, P. Tewary, A. Varadhachary, and J. J. Oppenheim, "Lactoferrin acts as an alarmin to promote the recruitment and activation of APCs and antigen-specific immune responses," The Journal of Immunology, vol. 180, no. 10, pp. 6868-6876, 2008.

[95] J. K. Actor, S. A. Hwang, M. Olsen, M. Zimecki, R. L. Hunter Jr., and M. L. Kruzel, "Lactoferrin immunomodulation of DTH response in mice," International Immunopharmacology, vol. 2, no. 4, pp. 475-486, 2002.

[96] S. A. Hwang and J. K. Actor, "Lactoferrin modulation of BCG-infected dendritic cell functions," International Immunology, vol. 21, no. 10, pp. 1185-1197, 2009.

[97] S. A. Hwang, K. M. Wilk, Y. A. Bangale, M. L. Kruzel, and J. K. Actor, "Lactoferrin modulation of IL-12 and IL-10 response from activated murine leukocytes," Medical Microbiology and Immunology, vol. 196, no. 3, pp. 171-180, 2007.

[98] S. A. Hwang, M. L. Kruzel, and J. K. Actor, "Lactoferrin augments BCG vaccine efficacy to generate $\mathrm{T}$ helper response and subsequent protection against challenge with virulent Mycobacterium tuberculosis," International Immunopharmacology, vol. 5, no. 3, pp. 591-599, 2005.

[99] K. J. Li, M. C. Lu, S. C. Hsieh et al., "Release of surface-expressed lactoferrin from polymorphonuclear neutrophils after contact with $\mathrm{CD} 4^{+} \mathrm{T}$ cells and its modulation on Th1/Th2 cytokine production," Journal of Leukocyte Biology, vol. 80, no. 2, pp. 350-358, 2006.

[100] I. Dhennin-Duthille, M. Masson, E. Damiens, C. Fillebeen, G. Spik, and J. Mazurier, "Lactoferrin upregulates the expression of CD4 antigen through the stimulation of the mitogen-activated protein kinase in the human lymphoblastic T Jurkat cell line," Journal of Cellular Biochemistry, vol. 79, no. 4, pp. 583-593, 2000.
[101] C. Guillen, I. B. McInnes, D. M. Vaughan et al., "Enhanced Th1 response to Staphylococcus aureus infection in human lactoferrin-transgenic mice," The Journal of Immunology, vol. 168, no. 8, pp. 3950-3957, 2002.

[102] B. Y. Bi, A. M. Lefebvre, D. Dus, G. Spik, and J. Mazurier, "Effect of lactoferrin on proliferation and differentiation of the Jurkat human lymphoblastic T cell line," Archivum Immunologiae et Therapiae Experimentalis, vol. 45, no. 4, pp. 315-320, 1997.

[103] M. Zimecki, J. Mazurier, M. Machnicki, Z. Wieczorek, J. Montreuil, and G. Spik, "Immunostimulatory activity of lactotransferrin and maturation of $\mathrm{CD} 4^{-} \mathrm{CD} 8^{-}$murine thymocytes," Immunology Letters, vol. 30, no. 1, pp. 119-123, 1991

[104] T. Kuhara, M. Iigo, T. Itoh et al., "Orally administered lactoferrin exerts an antimetastatic effect and enhances production of IL-18 in the intestinal epithelium," Nutrition and Cancer, vol. 38, no. 2, pp. 192-199, 2000.

[105] J. Artym, M. Zimecki, and M. L. Kruzel, "Reconstitution of the cellular immune response by lactoferrin in cyclophosphamide-treated mice is correlated with renewal of T cell compartment," Immunobiology, vol. 207, no. 3, pp. 197-205, 2003.

[106] A. M. van der Does, S. A. Joosten, E. Vroomans et al., "The antimicrobial peptide hLF1-11 drives monocyte-dendritic cell differentiation toward dendritic cells that promote antifungal responses and enhance Th17 polarization," Journal of Innate Immunity, vol. 4, no. 3, pp. 284-292, 2012.

[107] S. M. Nielsen, G. H. Hansen, and E. M. Danielsen, "Lactoferrin targets T cells in the small intestine," Journal of Gastroenterology, vol. 45, no. 11, pp. 1121-1128, 2010.

[108] M. Spadaro, C. Curcio, A. Varadhachary et al., "Requirement for IFN- $\gamma, \mathrm{CD}^{+} \mathrm{T}$ lymphocytes, and NKT cells in talactoferrin-induced inhibition of neu ${ }^{+}$tumors," Cancer Research, vol. 67, no. 13, pp. 6425-6432, 2007.

[109] J.-I. Togawa, H. Nagase, K. Tanaka et al., “Oral administration of lactoferrin reduces colitis in rats via modulation of the immune system and correction of cytokine imbalance," Journal of Gastroenterology and Hepatology, vol. 17, no. 12, pp. 1291-1298, 2002.

[110] L. A. Haversen, L. Baltzer, G. Dolphin, L. A. Hanson, and I. Mattsby-Baltzer, "Anti-inflammatory activities of human lactoferrin in acute dextran sulphate-induced colitis in mice," Scandinavian Journal of Immunology, vol. 57, no. 1, pp. 2-10, 2003.

[111] C. F. MacManus, C. B. Collins, T. T. Nguyen, R. W. Alfano, P. Jedlicka, and E. F. de Zoeten, "VEN-120, a recombinant human lactoferrin, promotes a regulatory $\mathrm{T}$ cell [Treg] phenotype and drives resolution of inflammation in distinct murine models of inflammatory bowel disease," Journal of Crohn's and Colitis, vol. 11, no. 9, pp. 1101-1112, 2017.

[112] R. M. Sfeir, M. Dubarry, P. N. Boyaka, M̀. Rautureau, and D. Tomé, "The mode of oral bovine lactoferrin administration influences mucosal and systemic immune responses in mice," The Journal of Nutrition, vol. 134, no. 2, pp. 403409, 2004.

[113] K. Slater and J. Fletcher, "Lactoferrin derived from neutrophils inhibits the mixed lymphocyte reaction," Blood, vol. 69 , no. 5 , pp. 1328-1333, 1987.

[114] M. Zimecki, J. Mazurier, G. Spik, and J. A. Kapp, "Lactoferrin inhibits proliferative response and cytokine production of 
TH1 but not TH2 cell lines," Archivum Immunologiae et Therapiae Experimentalis, vol. 44, no. 1, pp. 51-56, 1996.

[115] R. Rotondo, M. Bertolotto, G. Barisione et al., "Exocytosis of azurophil and arginase 1-containing granules by activated polymorphonuclear neutrophils is required to inhibit T lymphocyte proliferation," Journal of Leukocyte Biology, vol. 89, no. 5, pp. 721-727, 2011.

[116] P. C. Rodriguez, A. H. Zea, K. S. Culotta, J. Zabaleta, J. B. Ochoa, and A. C. Ochoa, "Regulation of $\mathrm{T}$ cell receptor CD3 $\zeta$ chain expression by L-arginine," The Journal of Biological Chemistry, vol. 277, no. 24, pp. 21123-21129, 2002.

[117] M. Munder, H. Schneider, C. Luckner et al., "Suppression of T-cell functions by human granulocyte arginase," Blood, vol. 108, no. 5, pp. 1627-1634, 2006.

[118] P. C. Rodriguez, D. G. Quiceno, and A. C. Ochoa, "L-Arginine availability regulates $\mathrm{T}$-lymphocyte cell-cycle progression," Blood, vol. 109, no. 4, pp. 1568-1573, 2007.

[119] J. Pillay, T. Tak, V. M. Kamp, and L. Koenderman, "Immune suppression by neutrophils and granulocytic myeloid-derived suppressor cells: similarities and differences," Cellular and Molecular Life Sciences, vol. 70, no. 20, pp. 3813-3827, 2013.

[120] N. Feldmeyer, G. Wabnitz, S. Leicht et al., "Arginine deficiency leads to impaired cofilin dephosphorylation in activated human T lymphocytes," International Immunology, vol. 24, no. 5, pp. 303-313, 2012.

[121] H. R. Yu, H. C. Kuo, L. T. Huang et al., "L-Arginine modulates neonatal lymphocyte proliferation through an interleukin-2 independent pathway," Immunology, vol. 143, no. 2, pp. 184-192, 2014.

[122] T. R. Sippel, T. Shimizu, F. Strnad, R. J. Traystman, P. S. Herson, and A. Waziri, "Arginase I release from activated neutrophils induces peripheral immunosuppression in a murine model of stroke," Journal of Cerebral Blood Flow \& Metabolism, vol. 35, no. 10, pp. 1657-1663, 2015.

[123] S. A. Ingersoll, J. Laval, O. A. Forrest et al., "Mature cystic fibrosis airway neutrophils suppress $\mathrm{T}$ cell function: evidence for a role of arginase 1 but not programmed death-ligand 1," The Journal of Immunology, vol. 194, no. 11, pp. 5520-5528, 2015.

[124] F. Morel, S. Berthier, M. Guillot et al., "Human neutrophil gelatinase is a collagenase type IV," Biochemical and Biophysical Research Communications, vol. 191, no. 1, pp. 269-274, 1993.

[125] F. C. Weber, T. Nemeth, J. Z. Csepregi et al., "Neutrophils are required for both the sensitization and elicitation phase of contact hypersensitivity," The Journal of Experimental Medicine, vol. 212, no. 1, pp. 15-22, 2015.

[126] T. Burster, H. Macmillan, T. Hou, B. O. Boehm, and E. D. Mellins, "Cathepsin G: roles in antigen presentation and beyond," Molecular Immunology, vol. 47, no. 4, pp. 658665, 2010.

[127] C. Stoeckle, V. Sommandas, E. Adamopoulou et al., "Cathep$\sin G$ is differentially expressed in primary human antigen-presenting cells," Cellular Immunology, vol. 255, no. 1-2, pp. 41-45, 2009.

[128] O. Chertov, H. Ueda, L. L. Xu et al., "Identification of human neutrophil-derived cathepsin G and azurocidin/CAP37 as chemoattractants for mononuclear cells and neutrophils," The Journal of Experimental Medicine, vol. 186, no. 5, pp. 739-747, 1997.
[129] V. Wittamer, B. Bondue, A. Guillabert, G. Vassart, M. Parmentier, and D. Communi, "Neutrophil-mediated maturation of chemerin: a link between innate and adaptive immunity," The Journal of Immunology, vol. 175, no. 1, pp. 487-493, 2005.

[130] R. Richter, R. Bistrian, S. Escher et al., "Quantum proteolytic activation of chemokine CCL15 by neutrophil granulocytes modulates mononuclear cell adhesiveness," The Journal of Immunology, vol. 175, no. 3, pp. 1599-1608, 2005.

[131] T. Yamazaki and Y. Aoki, "Cathepsin G binds to human lymphocytes," Journal of Leukocyte Biology, vol. 61, no. 1, pp. 7379, 1997.

[132] K. Tani, W. J. Murphy, O. Chertov, J. J. Oppenheim, and J. M. Wang, "The neutrophil granule protein cathepsin G activates murine T lymphocytes and upregulates antigen-specific IG production in mice," Biochemical and Biophysical Research Communications, vol. 282, no. 4, pp. 971-976, 2001.

[133] F. Zou, N. Schafer, D. Palesch et al., "Regulation of cathepsin $G$ reduces the activation of proinsulin-reactive $T$ cells from type 1 diabetes patients," PLoS One, vol. 6, no. 8, article e22815, 2011.

[134] F. Zou, X. Lai, J. Li, S. Lei, and L. Hu, "Downregulation of cathepsin $\mathrm{G}$ reduces the activation of $\mathrm{CD} 4+\mathrm{T}$ cells in murine autoimmune diabetes," American Journal of Translational Research, vol. 9, no. 11, pp. 5127-5137, 2017.

[135] Z. Fu, M. Thorpe, R. Alemayehu et al., "Highly selective cleavage of cytokines and chemokines by the human mast cell chymase and neutrophil cathepsin G," The Journal of Immunology, vol. 198, no. 4, pp. 1474-1483, 2017.

[136] J. K. Lim, W. Lu, O. Hartley, and A. L. DeVico, "N-terminal proteolytic processing by cathepsin $\mathrm{G}$ converts RANTES/CCL5 and related analogs into a truncated 4-68 variant," Journal of Leukocyte Biology, vol. 80, no. 6, pp. 1395-1404, 2006.

[137] O. H. Ryu, S. J. Choi, E. Firatli et al., "Proteolysis of macrophage inflammatory protein- $1 \alpha$ isoforms LD78 $\beta$ and LD78 $\alpha$ by neutrophil-derived serine proteases," The Journal of Biological Chemistry, vol. 280, no. 17, pp. 17415-17421, 2005.

[138] U. Bank, D. Reinhold, C. Schneemilch, D. Kunz, H. J. Synowitz, and S. Ansorge, "Selective proteolytic cleavage of IL-2 receptor and IL-6 receptor ligand binding chains by neutrophil-derived serine proteases at foci of inflammation," Journal of Interferon \& Cytokine Research, vol. 19, no. 11, pp. 1277-1287, 1999.

[139] G. Doring, F. Frank, C. Boudier, S. Herbert, B. Fleischer, and G. Bellon, "Cleavage of lymphocyte surface antigens CD2, $\mathrm{CD} 4$, and $\mathrm{CD} 8$ by polymorphonuclear leukocyte elastase and cathepsin G in patients with cystic fibrosis," The Journal of Immunology, vol. 154, no. 9, pp. 4842-4850, 1995.

[140] D. D. Kish, S. Min, N. Dvorina, W. M. Baldwin III, S. A. Stohlman, and R. L. Fairchild, "Neutrophil cathepsin G regulates dendritic cell production of IL-12 during development of CD4 T cell responses to antigens in the skin," The Journal of Immunology, vol. 202, no. 4, pp. 1045-1056, 2019.

[141] P. Saftig, M. Hetman, W. Schmahl et al., "Mice deficient for the lysosomal proteinase cathepsin D exhibit progressive atrophy of the intestinal mucosa and profound destruction of lymphoid cells," The EMBO Journal, vol. 14, no. 15, pp. 3599-3608, 1995.

[142] F. Liu, X. Li, C. Lu et al., "Ceramide activates lysosomal cathepsin B and cathepsin D to attenuate autophagy and 
induces ER stress to suppress myeloid-derived suppressor cells," Oncotarget, vol. 7, no. 51, pp. 83907-83925, 2016.

[143] P. Kolypetri, H. Jiang, and G. Carayanniotis, "Identification of pathogenic T cell epitopes near cathepsin cleavage sites in thyroglobulin," The Journal of Immunology, vol. 190, no. 4, pp. 1466-1471, 2013.

[144] C. . X. Moss, J. . A. Villadangos, and C. Watts, "Destructive potential of the aspartyl protease cathepsin D in MHC class II-restricted antigen processing," European Journal of Immunology, vol. 35, no. 12, pp. 3442-3451, 2005.

[145] E. W. Hewitt, A. Treumann, N. Morrice, P. J. Tatnell, J. Kay, and C. Watts, "Natural processing sites for human cathepsin $\mathrm{E}$ and cathepsin D in tetanus toxin: implications for T cell epitope generation," The Journal of Immunology, vol. 159, no. 10, pp. 4693-4699, 1997.

[146] B. Nakken, T. Varga, I. Szatmari et al., "Peroxisome proliferator-activated receptor $\gamma$-regulated cathepsin D is required for lipid antigen presentation by dendritic cells," The Journal of Immunology, vol. 187, no. 1, pp. 240-247, 2011.

[147] S. Conus, R. Perozzo, T. Reinheckel et al., "Caspase-8 is activated by cathepsin $\mathrm{D}$ initiating neutrophil apoptosis during the resolution of inflammation," The Journal of Experimental Medicine, vol. 205, no. 3, pp. 685-698, 2008.

[148] N. Bidere, H. K. Lorenzo, S. Carmona et al., "Cathepsin D triggers Bax activation, resulting in selective apoptosis-inducing factor (AIF) relocation in T lymphocytes entering the early commitment phase to apoptosis," The Journal of Biological Chemistry, vol. 278, no. 33, pp. 31401-31411, 2003.

[149] D. Ermert, C. F. Urban, B. Laube, C. Goosmann, A. Zychlinsky, and V. Brinkmann, "Mouse neutrophil extracellular traps in microbial infections," Journal of Innate Immunity, vol. 1, no. 3, pp. 181-193, 2009.

[150] T. Hoppenbrouwers, A. S. A. Autar, A. R. Sultan et al., "In vitro induction of NETosis: comprehensive live imaging comparison and systematic review," PLoS One, vol. 12, no. 5, article e0176472, 2017.

[151] E. F. Kenny, A. Herzig, R. Krüger et al., "Diverse stimuli engage different neutrophil extracellular trap pathways," eLife, vol. 6, 2017.

[152] S. Yousefi, C. Mihalache, E. Kozlowski, I. Schmid, and H. U. Simon, "Viable neutrophils release mitochondrial DNA to form neutrophil extracellular traps," Cell Death and Differentiation, vol. 16, no. 11, pp. 1438-1444, 2009.

[153] S. R. Clark, A. C. Ma, S. A. Tavener et al., "Platelet TLR4 activates neutrophil extracellular traps to ensnare bacteria in septic blood," Nature Medicine, vol. 13, no. 4, pp. 463-469, 2007.

[154] C. F. Urban, D. Ermert, M. Schmid et al., "Neutrophil extracellular traps contain calprotectin, a cytosolic protein complex involved in host defense against Candida albicans," PLoS Pathogens, vol. 5, no. 10, article e1000639, 2009.

[155] S. Sangaletti, C. Tripodo, C. Chiodoni et al., "Neutrophil extracellular traps mediate transfer of cytoplasmic neutrophil antigens to myeloid dendritic cells toward ANCA induction and associated autoimmunity," Blood, vol. 120, no. 15, pp. 3007-3018, 2012.

[156] G. S. Garcia-Romo, S. Caielli, B. Vega et al., "Netting neutrophils are major inducers of type I IFN production in pediatric systemic lupus erythematosus," Science Translational Medicine, vol. 3, no. 73, article 73ra20, 2011.
[157] G. Papadaki, K. Kambas, C. Choulaki et al., "Neutrophil extracellular traps exacerbate Th1-mediated autoimmune responses in rheumatoid arthritis by promoting DC maturation," European Journal of Immunology, vol. 46, no. 11, pp. 2542-2554, 2016.

[158] C. Carmona-Rivera, P. M. Carlucci, E. Moore et al., "Synovial fibroblast-neutrophil interactions promote pathogenic adaptive immunity in rheumatoid arthritis," Science Immunology, vol. 2, no. 10, article eaag3358, 2017.

[159] D. Scozzi, X. Wang, F. Liao et al., "Neutrophil extracellular trap fragments stimulate innate immune responses that prevent lung transplant tolerance," American Journal of Transplantation, 2018.

[160] S. L. Qiu, H. Zhang, Q. Y. Tang et al., "Neutrophil extracellular traps induced by cigarette smoke activate plasmacytoid dendritic cells," Thorax, vol. 72, no. 12, pp. 1084-1093, 2017.

[161] R. Lande, D. Ganguly, V. Facchinetti et al., "Neutrophils activate plasmacytoid dendritic cells by releasing self-DNA-peptide complexes in systemic lupus erythematosus," Science Translational Medicine, vol. 3, no. 73, article 73ra19, 2011.

[162] K. Tillack, P. Breiden, R. Martin, and M. Sospedra, "T lymphocyte priming by neutrophil extracellular traps links innate and adaptive immune responses," The Journal of Immunology, vol. 188, no. 7, pp. 3150-3159, 2012.

[163] M. Toussaint, D. J. Jackson, D. Swieboda et al., "Host DNA released by NETosis promotes rhinovirus-induced type- 2 allergic asthma exacerbation," Nature Medicine, vol. 23, no. 6, pp. 681-691, 2017.

[164] R. Sivanandham, E. Brocca-Cofano, N. Krampe et al., "Neutrophil extracellular trap production contributes to pathogenesis in SIV-infected nonhuman primates," The Journal of Clinical Investigation, vol. 128, no. 11, pp. 5178-5183, 2018.

[165] L. Barrientos, A. Bignon, C. Gueguen et al., "Neutrophil extracellular traps downregulate lipopolysaccharide-induced activation of monocyte-derived dendritic cells," The Journal of Immunology, vol. 193, no. 11, pp. 5689-5698, 2014.

[166] N. Krishnamoorthy, D. N. Douda, T. R. Brüggemann et al., "Neutrophil cytoplasts induce $\mathrm{T}_{\mathrm{H}} 17$ differentiation and skew inflammation toward neutrophilia in severe asthma," Science Immunology, vol. 3, no. 26, article eaao4747, 2018.

[167] D. Negorev, U. H. Beier, T. Zhang et al., "Human neutrophils can mimic myeloid-derived suppressor cells (PMN-MDSC) and suppress microbead or lectin-induced $\mathrm{T}$ cell proliferation through artefactual mechanisms," Scientific Reports, vol. 8, no. 1, p. 3135, 2018.

[168] O. Marini, S. Costa, D. Bevilacqua et al., "Mature $\mathrm{CD} 10^{+}$and immature $\mathrm{CD}^{-} 0^{-}$neutrophils present in G-CSF-treated donors display opposite effects on T cells," Blood, vol. 129, no. 10, pp. 1343-1356, 2017.

[169] K. Miles, D. J. Clarke, W. Lu et al., "Dying and necrotic neutrophils are anti-inflammatory secondary to the release of $\alpha$-defensins," The Journal of Immunology, vol. 183, no. 3, pp. 2122-2132, 2009.

[170] L. Bandholtz, G. J. Ekman, M. Vilhelmsson et al., “Antimicrobial peptide LL-37 internalized by immature human dendritic cells alters their phenotype," Scandinavian Journal of Immunology, vol. 63, no. 6, pp. 410-419, 2006. 


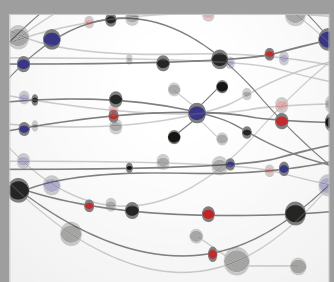

The Scientific World Journal
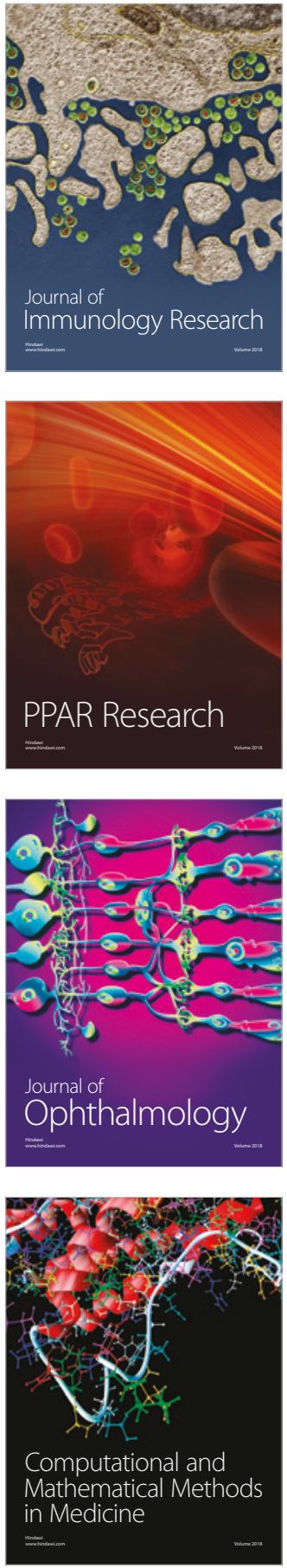

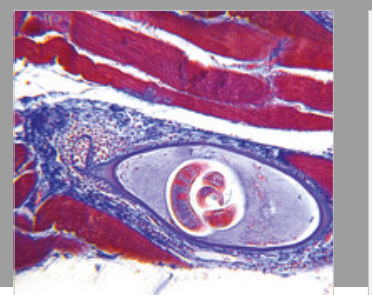

Gastroenterology Research and Practice

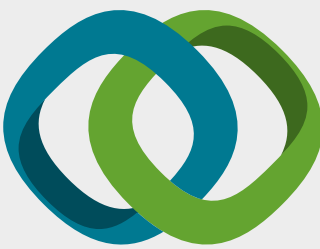

\section{Hindawi}

Submit your manuscripts at

www.hindawi.com
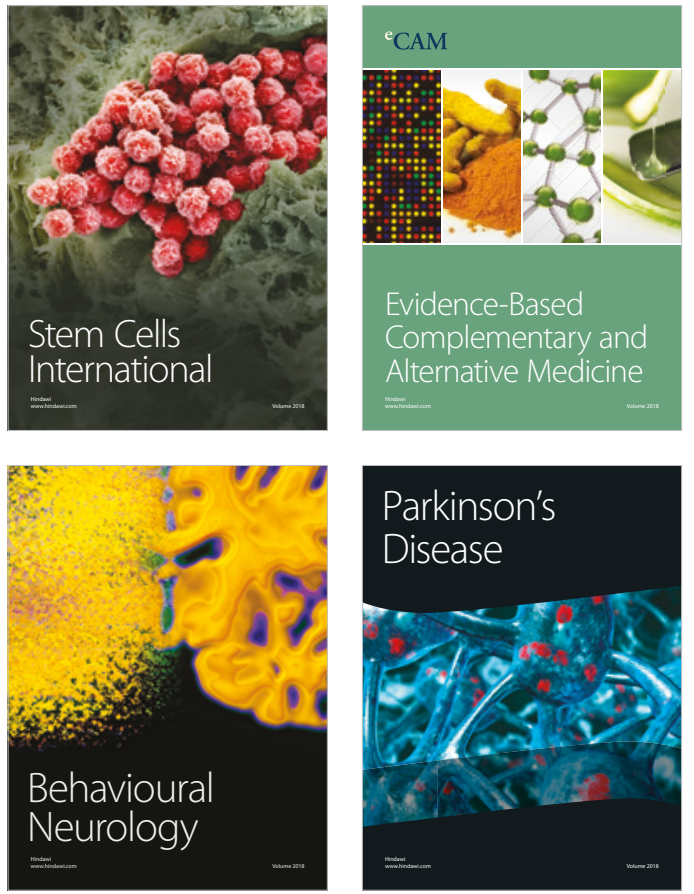

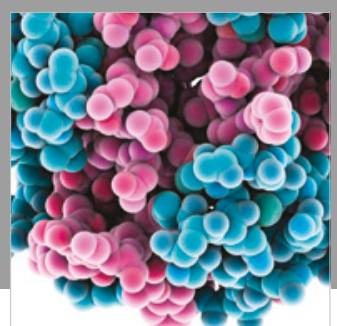

ournal of

Diabetes Research

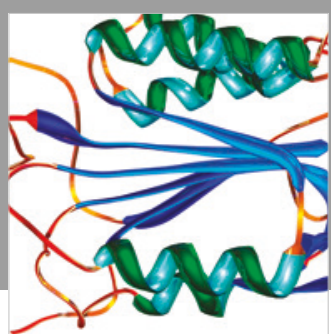

Disease Markers
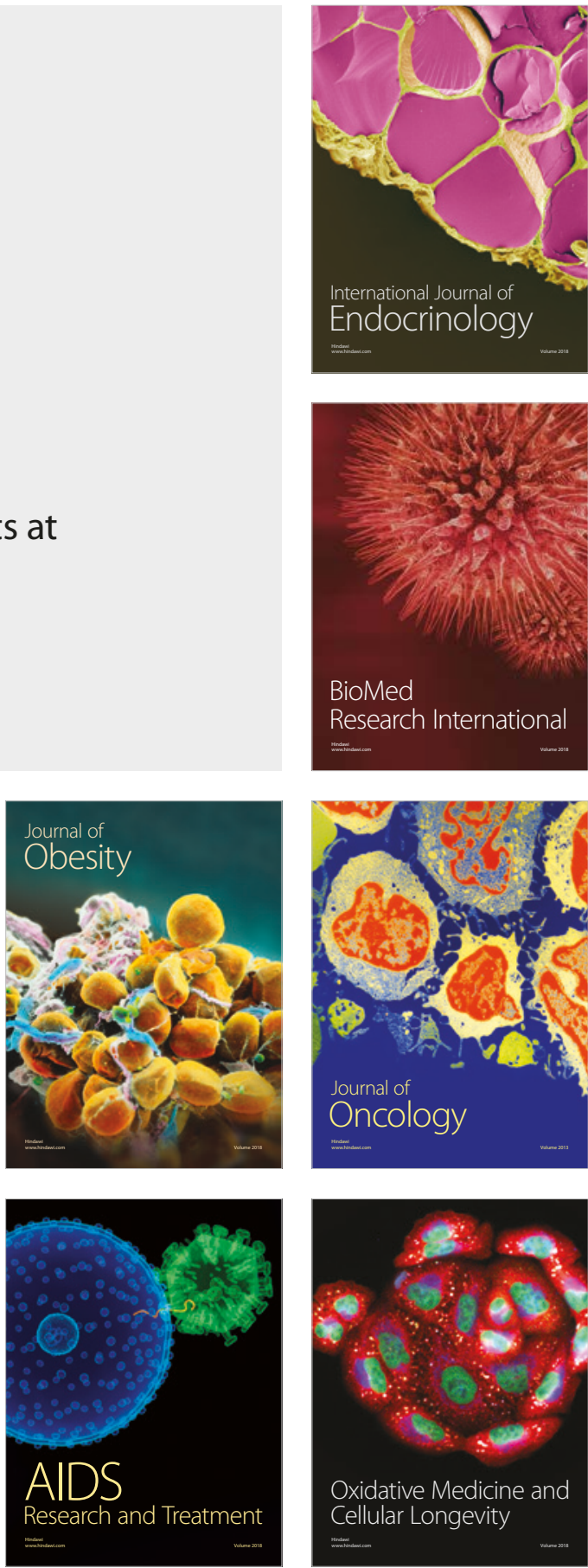